\title{
The Cytomegalovirus Protein Kinase pUL97: Host Interactions, Regulatory Mechanisms and Antiviral Drug Targeting
}

\author{
Mirjam Steingruber and Manfred Marschall * \\ Institute for Clinical and Molecular Virology, Friedrich-Alexander University of Erlangen-Nürnberg (FAU), \\ 91054 Erlangen, Germany; mirjam-steingruber@gmx.net \\ * Correspondence: manfred.marschall@fau.de; Tel.: +49-9131-85-26089
}

Received: 13 February 2020; Accepted: 2 April 2020; Published: 4 April 2020

\begin{abstract}
Human cytomegalovirus (HCMV) expresses a variety of viral regulatory proteins that undergo close interaction with host factors including viral-cellular multiprotein complexes. The HCMV protein kinase pUL97 represents a viral cyclin-dependent kinase ortholog (vCDK) that determines the efficiency of HCMV replication via phosphorylation of viral and cellular substrates. A hierarchy of functional importance of individual pUL97-mediated phosphorylation events has been discussed; however, the most pronounced pUL97-dependent phenotype could be assigned to viral nuclear egress, as illustrated by deletion of the UL97 gene or pharmacological pUL97 inhibition. Despite earlier data pointing to a cyclin-independent functionality, experimental evidence increasingly emphasized the role of pUL97-cyclin complexes. Consequently, the knowledge about pUL97 involvement in host interaction, viral nuclear egress and additional replicative steps led to the postulation of pUL97 as an antiviral target. Indeed, validation experiments in vitro and in vivo confirmed the sustainability of this approach. Consequently, current investigations of pUL97 in antiviral treatment go beyond the known pUL97-mediated ganciclovir prodrug activation and henceforward include pUL97-specific kinase inhibitors. Among a number of interesting small molecules analyzed in experimental and preclinical stages, maribavir is presently investigated in clinical studies and, in the near future, might represent a first kinase inhibitor applied in the field of antiviral therapy.
\end{abstract}

Keywords: human cytomegalovirus (HCMV); protein kinase pUL97; kinase-host interactions; cyclin/cyclin-dependent kinase complexes; regulatory mechanisms; antiviral drugs

\section{The Present Status of Controlling HCMV as a Major Human Pathogen}

\subsection{Molecular Biology of HCMV and Its Lytic Replication in Permissive Cells}

HCMV, the prototypic $\beta$-herpesvirus, represents a major human pathogen and is characterized by a multifaceted mode of virus-host interaction. HCMV seroprevalence in the adult population ranges between approximately $40 \%$ to $90 \%$ and reaches even higher levels, of more than $95 \%$, in countries with a low socio-economic standard [1]. HCMV exerts a strict species specificity and a comparably slow replication cycle spanning approximately three days in vitro [2,3]. Viral genomic DNA replication takes place in the nucleus and the double-stranded viral genome is packaged into capsids, which then undergo nuclear egress and budding through the nuclear membranes $[4,5]$. In the cytoplasmic virion assembly complex (cVAC), capsids are assembled with tegument proteins, before fully enveloped virus particles of approximately 150-200 nm are formed in the trans-Golgi network and released from the cell by final transition through the cytoplasmic membrane [2,6,7]. In addition to highly productive lytic infection of major target cells, such as fibroblasts, smooth muscle cells, endothelial 
and epithelial cells [8-12], HCMV causes life-long persistence by latent infection of minor target cells, such as monocytes/macrophages and $\mathrm{CD} 34^{+}$hematopoietic stem cells, in which latent HCMV may undergo reactivation resulting from immune insult, allogenic stimulation or differential signals (reviewed in [13]).

\subsection{Pathogenesis of HCMV Infection}

Due to the fact that primary and nonprimary infections (i.e., reactivation or reinfection) are mostly asymptomatic in healthy, immunocompetent individuals, HCMV infection usually remains clinically unrecognized. In contrast, patients with a compromised immune system, such as transplant recipients or AIDS patients, severely suffer from HCMV-related diseases, such as interstitial pneumonia, retinitis, gastroenteritis, esophagitis and organ failure, resulting in an increased mortality and morbidity [14-17]. Importantly, the immature immune system is a high risk factor for congenital cytomegalovirus infection (cCMV) of embryos and infants; thus, HCMV represents the most frequent cause for pathogen-derived developmental defects triggering mental retardation, loss of hearing or vision and microcephaly [18-24]. HCMV is one of few viruses that are able to cross the placenta efficiently, i.e., at least $33 \%$ of all primary infections during pregnancy of seronegative mothers, and an additional lower percentage of nonprimary infections undergo virus transmission resulting in cCMV infection of the unborn $[25,26]$. Thus, in Germany, approximately 3500 out of 700,000 newborns acquire cCMV per year [19]. Because of the lack of comprehensive HCMV screening, it is understood that approximately $10 \%$ of these are symptomatic at birth, including cases of stillbirth, and another $10 \%-15 \%$ may acquire symptoms at a later onset. HCMV can be transmitted by various body fluids, such as saliva, breast milk, vaginal secretions, semen and leukocytes containing blood and urine [27-31].

\subsection{Current Options of Prevention and Control}

Until today, no vaccine has been approved to control HCMV infections. Despite 60 years of intensive HCMV research, only a few antiviral drugs have been approved, which mostly interfere with the viral DNA polymerase pUL54, i.e., nucleoside/nucleotide analogs, such as the gold standard ganciclovir (GCV), its prodrug valganciclovir (VGCV), cidofovir (CDV) and the pyrophosphate analog foscarnet (FOS). Unfortunately, these drugs frequently cause severe side-effects, such as myelotoxicity, anemia and nephrotoxicity, or show poor bioavailability, which drives the selection of drug resistant virus variants [32-37]. In 2017, letermovir (LMV), the first anti-HCMV drug that targets the viral terminase complex consisting of pUL56, pUL89 and pUL51 core-subunits, was successfully assessed in clinical trials. Currently, LMV is approved for HCMV prophylaxis in hematopoietic stem cell transplantation recipients. LMV also represents a promising candidate for future combination therapies or even options of cCMV control [38-41]. However, based on the occurrence of LMV-resistant viral mutants [42] and the present lack of an approved treatment option for infants, the requirement of new antiviral drugs is still emphasized. This situation underlines the necessity of basic research to refine the understanding of the manifold and complex HCMV-host interplay and antiviral targeting strategies.

\section{HCMV-Encoded Protein Kinase pUL97, a Multifunctional CDK Ortholog (vCDK)}

\subsection{Characteristics of the HCMV-Encoded Protein Kinase}

pUL97 is a tegument protein, which is packaged into virions and is expressed with early-late kinetics [43]. The 707-amino acid protein exists in three isoforms due to alternative initiation of translation at residues M1, M74 or M157, resulting in protein varieties of approximately $100 \mathrm{kDa}$, $80 \mathrm{kDa}$ and $70 \mathrm{kDa}$, respectively (Table 1, Figure 1) [44]. The full-length kinase possesses two NLS sequences in the poorly structured N-terminus, which mediate the predominantly nuclear localization of pUL97 [45,46]. The kinase domain was assigned to the globular C-terminal part, amino acids 337-651, based on sequence homologies or extended to 337-706, based on biochemical validation [47-50]. An invariant lysine residue at position 355 is essential for kinase activity, thus leading to the catalytically 
inactive K355M mutant [51-53]. Dimers and oligomers are formed via the self-interaction domain (amino acids 231-280) of pUL97 [54]. Interestingly, the direct association of pUL97 with human cyclins has been demonstrated and, hereby, the core region responsible for cyclin T1 binding proved to be identical with the pUL97 self-interaction domain [55], thus illustrating a functional role of cyclins in pUL97 dimerization/oligomerization [52,56-58]. Concerning the properties of protein interaction and substrate phosphorylation of pUL97, a number of viral as well as cellular proteins have been identified thus far [see references in legend of Figure 1]. The functionality of these substrates spans various regulatory aspects of viral replication, such as nuclear egress, intrinsic immunity, genome replication and gene expression (Table 1, Figure 1). Notably, several of the pUL97-specific substrate proteins also represent substrates of cellular CDK-cyclin complexes and may thus underlie a process of dual phosphorylation through these two different kinds of protein kinases in HCMV-infected cells. While sequence conservation between the open reading frame ORF-UL97 and other kinases is generally low, functional and structural similarities have been identified between pUL97 and CDKs, so that pUL97 was termed as a multifunctional viral CDK ortholog (vCDK). Importantly, both deletion of ORF-UL97 or pharmacological inhibition of pUL97 activity resulted in a strong delay of HCMV replication [52,59-61], likewise explained by the fact that the kinase exerts many regulatory functions during viral replication (Table 1). On this basis, pUL97 could be validated as an interesting target for novel antiviral strategies and a panel of small molecule-type inhibitors of pUL97 activity belonging to different chemical classes has been described during the last years (see below, Sections 3-6). 
Table 1. Characterization of the molecular features and functional properties of the HCMV protein kinase pUL97.

\begin{tabular}{|c|c|c|c|c|}
\hline Property & General Description & Specific Feature & Own Findings (MM lab.) & Various References \\
\hline Type of kinase & Ser/Thr & $\begin{array}{l}\text { target site } \mathrm{P}+5 \text {, } \\
\text { target site LxSP }\end{array}$ & {$[51,53,56,62-64]$} & [65-69] \\
\hline Molecular mass, basic features & $100 / 80 / 70 \mathrm{kDa}$ & isoforms due to alternative translational start sites & {$[44,45,54]$} & {$[43,52,67]$} \\
\hline Expression pattern & $\begin{array}{l}\text { three isoforms M1, M74, M15 } \\
\text { (referring to other herpesviral } \\
\text { protein isoforms) }\end{array}$ & $\begin{array}{l}\text { differences in substrate binding, nuclear } \\
\text { translocation and drug susceptibility }\end{array}$ & {$[44,70]$} & {$[71-74]$} \\
\hline $\begin{array}{l}\text { Similarity and sequence } \\
\text { conservation with other } \\
\text { kinases }\end{array}$ & low & $\begin{array}{l}<35 \% \text { identity with herpesviral kinases, }<15 \% \\
\text { identity with cellular kinases }\end{array}$ & {$[45,63]$} & {$[48-50,75]$} \\
\hline $\begin{array}{l}\text { Sequence conservation } \\
\text { ORF-UL97 of HCMVs }\end{array}$ & high & $\begin{array}{l}\text { no variation of translational start sites, NLS } \\
\text { sequences or kinase domains }\end{array}$ & [44] & {$[76,77]$} \\
\hline Related to cell kinases & $\begin{array}{l}\text { cyclin-dependent kinases } \\
\text { (CDKs), viral CDK ortholog }\end{array}$ & $\begin{array}{c}\text { functional overlap with CDKs, specific crosstalk } \\
\text { with CDK9, CDK7 and CDK1, direct interaction } \\
\text { with cyclins }\end{array}$ & {$[47,55,56,78-83]$} & {$[57,84,85]$} \\
\hline $\begin{array}{l}\text { Coregulation of viral } \\
\text { replication by pUL97 and } \\
\text { cellular kinases }\end{array}$ & $\begin{array}{l}\text { several novel cellular kinases, } \\
\text { including CDKs, identified to be } \\
\text { involved in HCMV replication }\end{array}$ & $\begin{array}{l}\text { virus-supporting functions in signaling pathways } \\
\text { and nuclear capsid egress }\end{array}$ & {$[55,56,86,87]$} & [88-93] \\
\hline Substrate proteins & viral, cellular & $\begin{array}{l}\text { pUL44, pUL69, pp65, Rb, p32/gC1qR, nuclear } \\
\text { lamins, EF-18, RNAP II, IFI16, SAMHD1 }\end{array}$ & $\begin{array}{c}{[53,79,87,94-98]} \\
\text { (references therein) }\end{array}$ & $\begin{array}{l}{[57,75,84,99-106] \text { (see also }} \\
\quad \text { refs. in Figure 1) }\end{array}$ \\
\hline $\begin{array}{l}\text { Involvement in intrinsic } \\
\text { immunity evasion }\end{array}$ & $\begin{array}{l}\text { stimulation of viral } \\
\text { counterdefense of immunity }\end{array}$ & $\begin{array}{l}\text { interaction with cellular restriction factors IFI16 } \\
\text { and SAMHD1 }\end{array}$ & {$[96,107]$} & [108] \\
\hline Auto-phosphorylation & $\begin{array}{c}\text { pronounced } \\
\text { auto-phosphorylation activity, } \\
\text { several N-terminal Ser and Thr } \\
\text { residues } \\
\end{array}$ & $\begin{array}{l}\text { autophosphorylation most probably required for } \\
\text { kinase activity/autoactivation }\end{array}$ & {$[44,54,56,94,109]$} & {$[65,66,110]$} \\
\hline Nucleoside phosphorylation & $\begin{array}{l}\text { ganciclovir, valganciclovir, } \\
\text { penciclovir, acyclovir, etc. }\end{array}$ & $\begin{array}{l}\text { prodrug-activating monophosphorylation as an } \\
\text { essential step in antiviral therapy }\end{array}$ & {$[51,111]$} & {$[59,112-115]$} \\
\hline Incorporation into virions & component of virion tegument & $\begin{array}{l}\text { virion-derived pUL97 possesses highly detectable } \\
\text { kinase activity }\end{array}$ & {$[45,95]$} & {$[43,116,117]$} \\
\hline Intracellular localization & mainly nuclear & $\begin{array}{l}\text { two nuclear localization signals, NLS-1 (6-35), } \\
\text { NLS-2 (164-213), classical importin- } \alpha \text { pathway }\end{array}$ & {$[45,46,63,97,118]$} & {$[60]$} \\
\hline Inhibitors of pUL97 & $\begin{array}{l}\text { small molecules }(<500 \mathrm{Da} \text {, } \\
\text { various chemical classes) }\end{array}$ & $\begin{array}{c}\text { indolocarbazoles, benzimidazoles, quinazolines, } \\
\text { others }\end{array}$ & $\begin{array}{l}\text { [53] (references therein) } \\
{[44,64,119]}\end{array}$ & {$[114,120,121]$} \\
\hline $\begin{array}{l}\text { Phenotype of pUL97 } \\
\text { inhibition or UL97 deletion }\end{array}$ & $\begin{array}{l}\text { strongly reduced viral } \\
\text { replication efficiency } \\
\quad(100-1000 \text {-fold })\end{array}$ & $\begin{array}{l}\text { delayed replication kinetics; impaired genomic } \\
\text { replication; impaired viral nuclear egress }\end{array}$ & {$[44,51,53,94,109,122,123]$} & {$[59,61,104,124]$} \\
\hline
\end{tabular}


The interaction between HCMV pUL97 and human cyclins of the types B1, T1 and H has been described in our earlier reports $[47,55,82]$. The three cyclins obviously possess different affinities in terms of strength of pUL97 binding detected by coimmunoprecipitation (CoIP)- and mass spectrometry (MS)-based analyses. In case of cyclin B1, a requirement of catalytic activity of pUL97 for cyclin binding was identified, whereas in case of cyclin H, pUL97 interaction was found dependent on the environment of HCMV replication [82]. Recently published data indicate a substrate-bridging function of cyclin(s) for the binding of pUL97 to its substrate pp65, as determined with a pp65 mutant lacking a putative cyclin-docking motif [83].

Previous investigations led to the postulate of a substantial relevance of pUL97-cyclin interactions, as characterized by the following findings: (i) The HCMV kinase pUL97 acts as a structural CDK ortholog originally based on our bioinformatic modeling and biochemical analyses. (ii) Our initial report on pUL97-cyclin T1 interaction could be extended to additional types such as cyclins B1 and $H[47,55,56,82]$. (iii) The interaction pUL97-cyclins B1/T1/H was confirmed by several methods including highly sensitive mass spectrometry-based proteomics. (iv) Specifically, the interaction pUL97-cyclin B1 was found to be phosphorylation-dependent for both proteins. In addition, cyclin B1 (but not $\mathrm{H}$ ) was phosphorylated by pUL97 in vitro [56]. (v) Using a protein assembly-based CoIP assay, the formation of binary and ternary complexes involving pUL97, cyclin H and CDK7 was identified, thus suggesting a cyclin bridging concept [125]. A central finding was that regions responsible for cyclin T1 interaction of pUL97 and pUL97-pUL97 self-interaction showed an overlap in N-terminal amino acids 231-280 (Figure $1 ;[54,55]$ ). These data strongly suggest that cyclin binding is involved in pUL97-pUL97 self-interaction and very recent findings specified this activity for cyclin types T1 and $\mathrm{H}$ (but not $\mathrm{B} 1$ ), thus confirming the bridging function of cyclins $\mathrm{T} 1 / \mathrm{H}$ in $\mathrm{pUL} 97$ dimerization or hetero-oligomerization. This self-interaction property is known to be a factor required for developing full catalytic activity of the pUL97 kinase [see references in Table 1]. The amino acid region 231-280 of pUL97 is considered as a minimal binding region for cyclin T1, which may be complemented by the additional binding of globular domain interfaces of pUL97 in the further C-terminal region, contributing to cyclin binding in a type-specific manner (cyclin T1, amino acids 361-532; cyclin B1, 363-647; cyclin H, 328-532; Figure 1; [56,82]).

In order to address the question of which spectrum of different types of human cyclins may associate with the viral pUL97 kinase, two specific experimental approaches have recently been performed. Firstly, a recombinant HCMV expressing a Flag-tagged version of pUL97 (namely the largest, fully functional isoform M1 of pUL97 encoded by HCMV AD169-UL97(Mx4)-Flag; [44]) was used for Flag-specific coimmunoprecipitation settings. The CoIP samples were then applied in a mass spectrometry-based (MS) proteomic assessment of pUL97-associated viral (Table S1) and cellular proteins (Table S2). HCMV AD169, expressing untagged pUL97, was used as a CoIP/MS specificity control. The identified viral proteins included several known interactors and/or substrates of pUL97 and showed a substantial overlap with those detected in our similar approach performed earlier, as based on the CoIP of pUL97-cyclin complexes using cyclin-specific antibodies [82]. Cellular proteins identified by this approach contained cyclins, CDKs and additional host proteins confirming earlier findings of pUL97-specific protein complexes. Notably, cyclins T1 and B1 were again safely detected, as those types of cyclins had been found by a variety of methodological approaches before (summarized in Table 2). Secondly, a panel of cyclin-specific antibodies were employed in a broader setting of CoIP analysis to learn more about the overall spectrum of pUL97-cyclin interaction. Representative members of the functional groups of cyclin types have been chosen, i.e., B-like, C-like and Y-like cyclins (Table 2, Supplementary Materials Figure S1). To this end, the cyclin-specific CoIP of pUL97 was then performed, again on the basis of total lysates prepared from HCMV-infected primary fibroblasts, followed by a quantitative assessment based on densitometric measurements (in duplicates, using two series of stained CoIP/Wb filters). The results, on the one hand, confirmed our earlier postulate that pUL97 strongly interacts with cyclin types B1, T1 and H (the latter primarily with pUL97 expressed in HCMV-infected cells, but very poorly with pUL97 transiently expressed in transfection-based 
settings; [56,82]). On the other hand, even more types of human cyclins could be additionally detected, either with moderate/weak (cyclins E, F and Y) or strong (cyclins B2 and K) properties of pUL97 interaction (Figure S1, Table S3 and Table 2). This topic of cyclin specificity of pUL97 and its functional relevance for HCMV replication will be further investigated by the use of recombinant HCMVs expressing mutant versions of pUL97 carrying cyclin-binding defects.

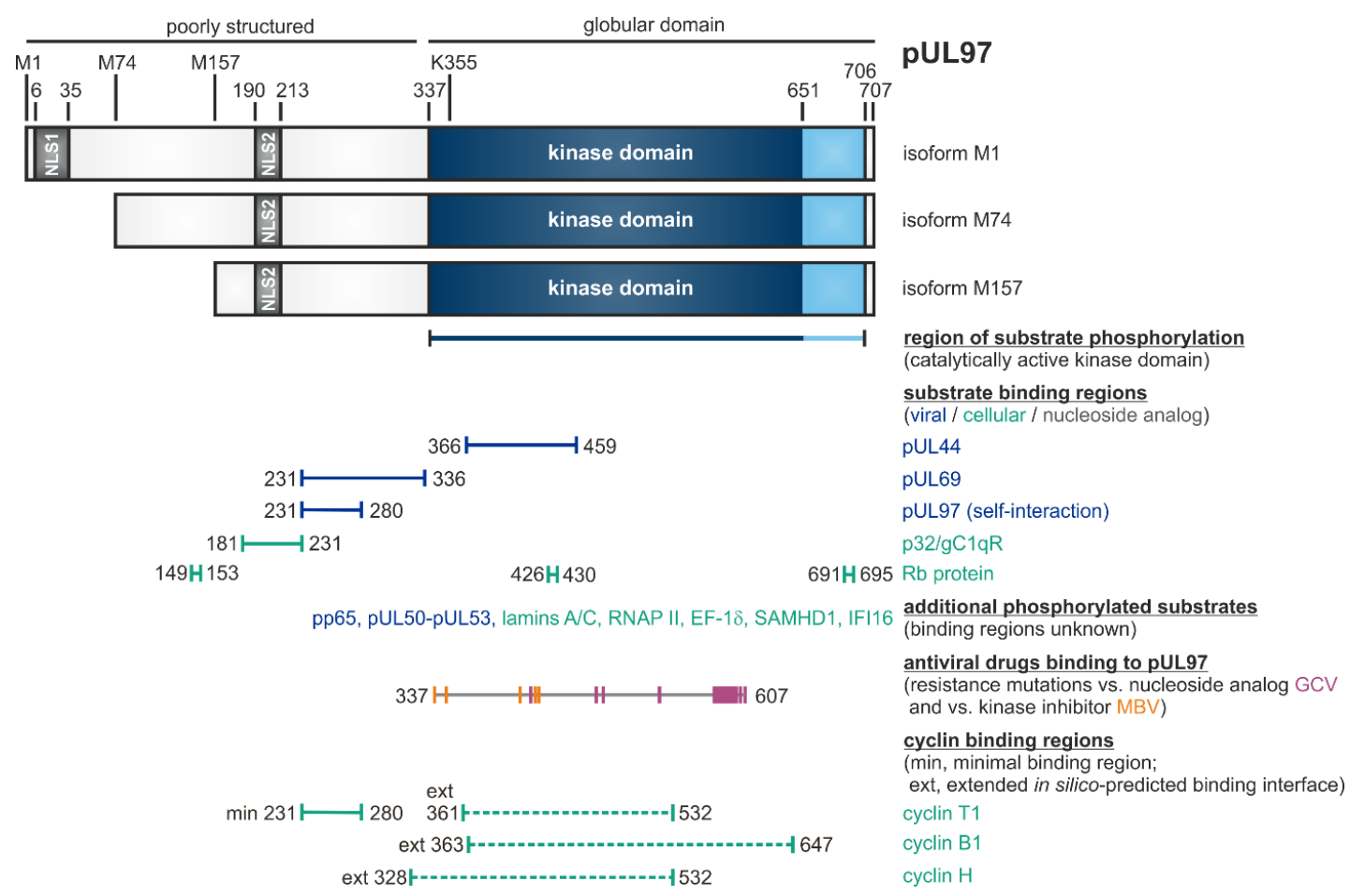

Figure 1. Schematic illustration of the modular structure and the so far identified binding regions within pUL97 [56]. The kinase domain is located between amino acids 337 and 706, as based on biochemical validation (or 337 and 651, as based on sequence homologies). K355 is an invariant lysine residue required for kinase activity. Expression of three pUL97 isoforms is determined by alternative translational initiation sites at M1, M74 and M157. Two nuclear localization signals (NLS1 and NLS2) are contained in the N-terminal unstructured portion of pUL97. Self-interaction/oligomerization of pUL97 is determined by amino acid region 231-280. This region overlaps with a minimal binding region for cyclin T1. Recent modeling approaches based on the in silico prediction of binding interfaces suggested extended binding interfaces for cyclins T1, B1 and H. Moreover, pUL97 is involved in the multiple regulatory steps during HCMV replication through the phosphorylation of viral and cellular substrates (see horizontal bars), as reported by several independent groups [44-46,54,55,57,75,79-84,94-101,122,126-132]. Substrates include the viral DNA polymerase cofactor pUL44, viral RNA transport factor pUL69, major tegument protein pp65, nuclear egress core protein heterodimer pUL50-pUL53, cellular multi-ligand binding protein $\mathrm{p} 32 / \mathrm{gC1qR}$, tumor suppressor/checkpoint protein $\mathrm{Rb}$, nuclear lamins $\mathrm{A} / \mathrm{C}$, RNA polymerase II, translation factor EF-1 $\delta$, interferon-inducible proteins IFI16 and SAMHD1, as well as the therapeutically applied nucleoside analog ganciclovir (GCV; [47,56,82] and references therein). Interaction regions for GCV and the ATP-competitive pUL97 inhibitor maribavir (MBV) were defined by the location of resistance mutations detected so far (GCV: 405, 460, 466, 520, 590, 591, 592, 594, 595, 596, 597, 598, 599, 600, 601, 603, 607; MBV: 337, 353, 397, 409,411). Note that this Figure represents a refined update, as adapted from an earlier version published elsewhere [56]; here, this also includes the hitherto mapped regions of resistance mutations against GCV and $\mathrm{MBV}$, which possess high relevance for the discussion of an advanced antiviral drug targeting. 
Table 2. Summarized findings of pUL97-cyclin interaction derived from complementary experimental settings *.

\begin{tabular}{|c|c|c|c|c|c|c|c|c|}
\hline & \multicolumn{5}{|c|}{ A HCMV-Infected Cells } & \multicolumn{3}{|c|}{ B Recombinant Expression } \\
\hline & Cyclin Types & Cyclin IP MS|Wb & pUL9 & $\mathrm{Wb}$ & $\begin{array}{l}\text { Colocalization } \\
\text { in IF }\end{array}$ & Transfection & $\begin{array}{c}\text { Yeast } \\
\text { Two-Hybrid } \\
\text { System }\end{array}$ & $\begin{array}{l}\text { Phosphorylation } \\
\text { by pUL97 in } \\
\text { IVKA }\end{array}$ \\
\hline \multirow{6}{*}{ B-like } & Cyclin A & \pm & - & - & .. & .. & .. & .. \\
\hline & Cyclin B1 & + & + & - & + & + & .. & + \\
\hline & Cyclin B2 & + & - & - & - & .. & .. & .. \\
\hline & Cyclin D1 & - & - & - & - & - & .. & \\
\hline & Cyclin E & \pm & - & - &.. & .. &.. &.. \\
\hline & Cyclin F & \pm & - & - &.. &.. & .. &.. \\
\hline \multirow{4}{*}{ C-like } & Cyclin H & + & - & - & + & - & - & - \\
\hline & Cyclin K & + & - & - & .. &.. & .. & .. \\
\hline & Cyclin L2a & .. & - & - & & .. & .. & .. \\
\hline & Cyclin T1 & + & + & + & + & + & + & - \\
\hline Y-like & Cyclin $Y$ & \pm & - & - &.. &.. &.. &.. \\
\hline \multicolumn{9}{|c|}{$\begin{array}{l}\text { * Data on pUL97-cyclin interaction were derived from the experimental settings of either mass spectrometry-based } \\
\text { proteomics (MS) or Western blot detection (Wb), both performed by the use of coimmunoprecipitates derived } \\
\text { from cyclin-specific immunoprecipitation (cyclin IP) or pUL97 immunoprecipitation (pUL97 IP). Colocalization } \\
\text { patterns between pUL97 and individual cyclins, in particular nuclear punctate patterns of accumulation in viral } \\
\text { replication centers, were determined by indirect immunofluorescence (IF) double-staining and confocal imaging. } \\
\text { Recombinant expression of pUL97 and/or cyclins was performed by transient transfected of } 293 \mathrm{~T} \text { cells (transfection), } \\
\text { yeast cells (yeast two-hybrid assay) or bacterial expression systems, the latter for analyzing the phosphorylation } \\
\text { of recombinant cyclins by transfection-derived pUL97 in the in vitro kinase assay (IVKA). In panel A, the criteria } \\
\text { of categorization were set as follows: }+ \text {, strong pUL97-cyclin interaction (MS: WSC } \geq 4 ; \text { Wb: \% IP values }>20 \% \\
\text { IP control and } \geq 15 \text {-fold above Flag neg. control); } \pm \text {, weak interaction (MS: WSC }=3 \text {; Wb: \% IP values }>20 \% \text { IP } \\
\text { control or } \geq 15 \text {-fold above Flag neg. control); -, no detectable interaction; ..., not determined. Note that the combined } \\
\text { experimental data provide strongest evidence for cyclins B1, H and T1 to represent the major cyclin types interacting } \\
\text { with pUL97, as highlighted by bolt print. }\end{array}$} \\
\hline
\end{tabular}

\subsection{Phosphorylation of a Panel of Regulatory Viral Proteins and Host Factors through pUL97}

Notably, pUL97 phosphorylates several viral and cellular proteins (see horizontal bars in Figure 1 for those binding regions within pUL97 that have been mapped thus far), including the viral DNA polymerase cofactor pUL44 [122], viral RNA transport factor pUL69 [79], major tegument protein pp65 [95], nuclear egress core proteins pUL50-pUL53 [99,127], cellular multiligand binding protein p32/gC1qR [98,122], tumor suppressor protein Rb [75], nuclear lamins A/C [57,84,94,98,129], RNAP II [100], translation factor EF-1 [63,101,130], interferon-inducible, intrinsic immune restriction factors IFI16 [96] and SAMHD1 [105] (Figure 2; Table 3; compare with Tables S1-S3).

It should be emphasized that the pUL97 substrate proteins belong to several functionally different groups (Table 3), thus underlining the multifunctional nature of this singly expressed viral protein kinase. Viral proteins interacting with and being phosphorylated by pUL97 span the regulatory areas of viral nuclear egress (pUL50-pUL53 core NEC), genome replication (pUL44), tegumentation and immune-regulatory functions (pp65), viral RNA transport (pUL69) and the pUL97-pUL97 autophosphorylation/autoregulation associated with the formation of dimers and oligomers. As far as cellular substrates are concerned, the following regulatory areas are addressed: nuclear egress (lamins $\mathrm{A} / \mathrm{C}$, p32/gC1qR), cell cycle control (Rb, cyclins), intrinsic immune regulation (IFI16, SAMHD1) and transcription/translation (RNAP II, EF-18). The entity of this spectrum of pUL97-driven processes in virus-infected cells illustrates the functional importance of pUL97 for a high efficiency of viral replication, as demonstrated by the defects of recombinant viruses carrying UL97 deletions/mutations (up to factor 100-1000). Interestingly, the dimension of a replication defect resulting from drug-inhibited pUL97 was demonstrated to be more drastic in non-cycling compared to cycling cells [133], probably referring to the crosstalk and functional complementation between active cellular CDK-cyclin complexes and the vCDK. Moreover, the complex patterns of protein-protein interactions (PPI) undergone by pUL97 have recently been revealed by the use of highly sensitive mass spectrometry-based proteomic and phosphoproteomic approaches $[56,66,82,98]$. These findings make the occurrence of higher-order, pUL97-associated PPI complexes seem highly likely. 
Table 3. Characteristics of viral and cellular substrate proteins of the HCMV vCDK pUL97 as well as pUL97-associated cyclins.

\begin{tabular}{|c|c|c|c|c|}
\hline Protein Origin & Designation & Function & Remarks & References \\
\hline Viral & pUL50 & core nuclear egress protein (NEC) & $\begin{array}{l}\text { forms the NEC groove, multiple PPIs, } \\
\text { phosphorylated by viral and cellular kinases }\end{array}$ & {$[62,99,126,127,134,135]$} \\
\hline Viral & pUL53 & core nuclear egress protein (NEC) & $\begin{array}{l}\text { forms NEC hook, possibly docking to } \\
\text { capsids, phosphorylated by viral kinase }\end{array}$ & {$[99,136,137]$} \\
\hline Viral & pUL44 & $\begin{array}{l}\text { DNA polymerase pUL54 processivity } \\
\text { factor }\end{array}$ & phosphorylation might regulate activity & {$[104,122]$} \\
\hline Viral & pp65 & major tegument protein & $\begin{array}{l}\text { massively phosphorylated and } \\
\text { virion-associated with pUL97 }\end{array}$ & {$[44,60,95]$} \\
\hline Viral & pUL69 & RNA transport regulator & phosphorylation regulates activity & {$[78,79,138,139]$} \\
\hline Viral & pUL97 & $\begin{array}{l}\text { CDK-like serine/threonine protein } \\
\text { kinase, multifunctional }\end{array}$ & dimers/oligomers, autophosphorylation & {$[50,53,54,65,110,114,132]$} \\
\hline Cellular & $\mathrm{p} 32 / \mathrm{gC} 1 \mathrm{qR}$ & $\begin{array}{l}\text { multiligand binding protein, } \\
\text { multifunctional }\end{array}$ & NEC bridging factor & {$[94,98,140]$} \\
\hline Cellular & lamins $\mathrm{A} / \mathrm{C}$ & $\begin{array}{l}\text { structural and regulatory components } \\
\text { of the nuclear envelope }\end{array}$ & $\begin{array}{c}\text { lamin phosphorylation is a rate-limiting step } \\
\text { of viral nuclear egress }\end{array}$ & {$[57,84,94,97,129,141]$} \\
\hline Cellular & $\mathrm{Rb}$ & $\begin{array}{l}\text { retinoblastoma protein, cell cycle } \\
\text { check-point regulator }\end{array}$ & $\begin{array}{c}\text { multiply phosphorylated by CDKs and } \\
\text { pUL97 }\end{array}$ & {$[48,57,85,103,106]$} \\
\hline Cellular & IFI16 and SAMHD1 & $\begin{array}{l}\text { intrinsic immune restriction factors of } \\
\text { virus infections }\end{array}$ & $\begin{array}{l}\text { interferon-induced, } \\
\text { phosphorylation-controlled }\end{array}$ & {$[96,105,107,108,142]$} \\
\hline Cellular & RNAP II & main cellular mRNA transcriptase & $\begin{array}{l}\text { activity-regulated by C-terminal } \\
\text { phosphorylation (CTD) }\end{array}$ & {$[59,61,90,100]$} \\
\hline Cellular & $\mathrm{EF}-1$ & translation elongation factor 1 delta & activity-regulated by phosphorylation & {$[53,101]$} \\
\hline Cellular & cyclins & regulatory subunits of CDKs & $\begin{array}{l}\text { types B1, H, T1 were found pUL97-associated } \\
\text { (possibly also B2, K, others) }\end{array}$ & {$[55,56,58,84,92]$} \\
\hline
\end{tabular}




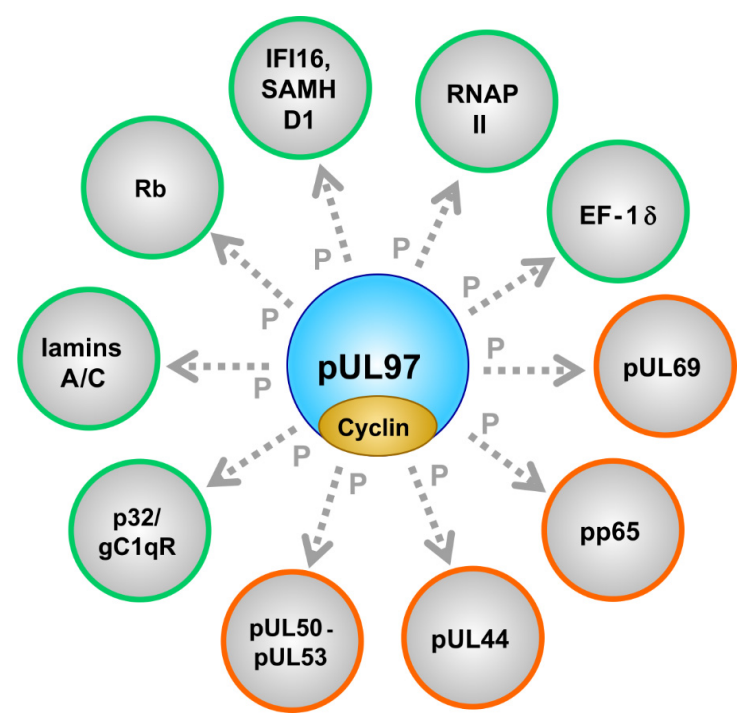

Figure 2. The cytomegalovirus-encoded CDK-like protein kinase pUL97 interacts with cyclins and phosphorylates a number of viral (encircled in orange) and cellular (encircled in green) substrate proteins.

\subsection{HCMV pUL97 and Related Herpesviral vCDKs}

Most pUL97-related herpesviral kinases function as viral CDK orthologs (vCDKs). They were also termed conserved herpesviral protein kinases (CHPKs), as encoded by a gene conserved throughout the family Herpesviridae (e.g., prototype pUL97 and homologous kinases). Despite conservation of the UL97 gene locus, substantial variation of the primary coding sequence has been identified between herpesviruses. In addition to CHPKs, a second protein kinase is encoded by an additional non-conserved gene restricted to the subfamily $\alpha$-Herpesvirinae (e.g., prototype pUS3 kinase of herpes simplex virus). CDK activity has been shown to be involved in multiple steps during HCMV infection [143]. vCDKs phosphorylate typical CDK substrates such as $\mathrm{Rb}$ and lamins $\mathrm{A} / \mathrm{C}$ and show $\mathrm{CDK}$ activity in a yeast complementation assay $[57,75,84,129]$. The Saccharomyces cerevisiae mutant lacking activity of its sole CDK, cdc28, shows growth arrest in the early S/late G1 phase, which is overcome by CDK1 (human), pUL97 (HCMV), pU69 (HHV-6 and -7) and BGLF4 (EBV) expression [57]. In addition, pUL97 and CDK share substrate proteins, such as pUL69, RNAP II and EF-18 [78,79,101,130]. Of note, pUL97 and CDKs phosphorylate $\mathrm{Rb}$ at the same residues (S780, S807, T821), leading to the inactivation of the cell cycle-inhibitory and tumor suppressor functions of $\mathrm{Rb}[75,144,145]$ (Table 4 ). In addition, the suppression of CDKs 1, 2, 5 and 9 by indirubin-derivatives increases the HCMV-inhibitory effect of maribavir (MBV), a potent pUL97 inhibitor [58]. Thus, pUL97 and CDKs possess at least partially overlapping functions. 
Table 4. Comparison of distinct molecular characteristics shared between vCDK pUL97 and human CDKs.

\begin{tabular}{|c|c|c|c|c|}
\hline Kinase Characteristics & pUL97 & CDK1 & CDK7 & CDK9 \\
\hline Amino acids (aa) & 707 & 297 & 345 & 372 \\
\hline Aa sequence identity to pUL97 & $100 \%$ & $4.5 \%$ & $4.2 \%$ & $8.6 \%$ \\
\hline $\begin{array}{c}\text { Cyclin binding partner } \\
{[56,146,147]}\end{array}$ & $\begin{array}{l}\text { cyclin } \mathrm{B} 1 \\
\text { cyclin } \mathrm{H} \\
\text { cyclin } \mathrm{T} 1\end{array}$ & $\begin{array}{l}\text { cyclin A1/A2 } \\
\text { cyclin B1/B2/B3 } \\
\text { cyclin D1/D3 } \\
\text { cyclin F } \\
\text { cyclin K } \\
\text { (activating) }\end{array}$ & $\begin{array}{c}\text { cyclin } \mathrm{H} \\
\text { cyclin } \mathrm{A} 2 \\
\text { cyclin } \mathrm{B} 1 / \mathrm{B} 2 \\
\text { cyclin } \mathrm{E} \\
\text { (activating) }\end{array}$ & $\begin{array}{l}\text { cyclin } \mathrm{T} 1 / \mathrm{T} 2 \\
\text { cyclin } \mathrm{H} \\
\text { cyclin } \mathrm{K} \\
\text { (activating) }\end{array}$ \\
\hline $\begin{array}{l}\text { Region in the kinase required } \\
\text { for cyclin binding }[55,148,149]\end{array}$ & $\begin{array}{c}\text { cyclin T1: } \\
{ }^{231} \text { ESQDSAVASGPGRIPQPLSG } \\
\text { SSGEESATAVEADSTSHDDVH } \\
\text { CTCSNDQII } 80 \text { and in } \\
\text { silico-predicted binding } \\
\text { interfaces for cyclins B1, H and } \\
\text { T1 spanning aa } 328-647\end{array}$ & $\begin{array}{l}\text { cyclin B1: a positively charged } \\
\text { region in the N-lobe (containing } \\
\text { K6, K9, K34, R36, R75, } \\
\text { excluding the PSTAIRE helix) } \\
\text { cyclin A2: }{ }^{45} \text { PSTAIRE }^{51}\end{array}$ & cyclin H: ${ }^{56}$ NRTALRE $^{62}$ & cyclin T1/T2, K: ${ }^{60} \mathrm{PITALRE}^{66}$ \\
\hline $\begin{array}{l}\text { Cyclin phosphorylation } \\
{[56,82,146,150-153]}\end{array}$ & cyclin B1 & $\begin{array}{l}\text { cyclin B1 S126 by CDK1 S128 by } \\
\text { CDK1 }\end{array}$ & $\begin{array}{c}\text { cyclin H by CDK7/CDK8-cyclin } \\
\text { C (inhibitory) }\end{array}$ & n.d.* \\
\hline $\begin{array}{c}\text { T-loop phosphorylation } \\
{[56,154-161]}\end{array}$ & no, (possibly S483) & T161 by CAK (activating) & $\begin{array}{l}\text { S164 and T170 by CDK1/CDK2 } \\
\text { (activating) }\end{array}$ & $\begin{array}{l}\text { T186 by CaMK1D or CDK } 9 \\
\text { (S175 by CAK, not essential } \\
\text { for activity) }\end{array}$ \\
\hline $\begin{array}{c}\text { Autophosphorylation } \\
{[110,155,156]}\end{array}$ & yes & no & (yes) outside the T-loop & yes within the T-loop \\
\hline $\begin{array}{c}\text { Rb phosphorylation } \\
{[66,75,82,145,162,163]}\end{array}$ & $\begin{array}{c}\text { S780, S807, S811, T821, T823, } \\
\text { T826 }\end{array}$ & S249, T252, T373, S807, S811 & no & C-terminus (793-834) \\
\hline p53 phosphorylation [164-166] & n.d. & S315 & S33 (MAT1-dependent) & S33, S315, S392 \\
\hline $\begin{array}{c}\text { Lamin } \mathrm{A} / \mathrm{C} \text { phosphorylation } \\
{[84,141,167,168]}\end{array}$ & S22 (inhibitory) & S22, S392 (inhibitory) & no & no \\
\hline $\begin{array}{c}\text { CTD RNAP II } \\
\text { phosphorylation }[100,169,170]\end{array}$ & S2, S5 (activating) & no & S2, S5, S7 (activating) & S2, S5, S7 (activating) \\
\hline $\begin{array}{c}\text { SAMHD1 phosphorylation } \\
{[171-173]}\end{array}$ & yes & T592 & n.d. & n.d. \\
\hline $\begin{array}{c}\text { HCMV pUL69 } \\
\text { phosphorylation }[78,79]\end{array}$ & yes & yes & yes & yes \\
\hline $\begin{array}{c}\text { HCMV pUL50 } \\
\text { phosphorylation [127] }\end{array}$ & yes & yes & n.d. & n.d. \\
\hline
\end{tabular}

*n.d., not determined. 


\section{Validation of vCDK pUL97 as an Antiviral Target and Various pUL97 Inhibitors Explored as Experimental Antiviral Drugs}

\subsection{Role of the pUL97 Kinase in Anti-HCMV Standard Therapy}

The HCMV-encoded CDK ortholog pUL97 has significance in the therapy of HCMV infections, as it is responsible for the phosphorylation-mediated activation of GCV/VGCV, still representing the therapy gold standard and, similarly, additional nucleosides such as acyclovir (ACV), penciclovir (PCV) and others $[69,113,174]$. Hereby, the specific role of pUL97 is that nucleoside analogs have to be initially monophosphorylated in a step catalyzed by pUL97 kinase [68]. Thereafter, the active triphosphate metabolites have to be generated in a series of steps of further phosphorylation catalyzed by human guanylate kinase, dGMP kinase, phosphoglycerate kinase and potentially other host kinases [25]. In the triphosphate form, these analogs represent the active antiviral determinants, then acting as a substrate of the HCMV DNA polymerase, ultimately inhibiting the elongation of viral genome synthesis.

\subsection{Target Validation and pUL97 Inhibitors}

Genetic mutation studies showed that pUL97 plays a rate-limiting regulatory role for the replication efficiency of HCMV and virus titers were reduced by orders of magnitude when the coding sequence was disrupted [59,61]. Moreover, pharmacological inhibition of pUL97 activity by small molecules derived from various chemical classes blocked viral replication in a manner corresponding to the pUL97 null phenotype and thus proved to be a potent antiviral targeting strategy [175]. Since then, the pharmacologic inhibition of pUL97 activity together with genetic techniques have helped to characterize the mechanisms of pUL97 supporting the viral replication and virus-host kinase interactions $[52,53,56,176]$. A number of inhibitors of pUL97 kinase activity have been identified that exert potent antiviral activity against HCMV $[64,119,175,177]$. These include indolocarbazoles [51,109,120], quinazolines [64,123,178] and benzimidazole analogs [175] (Figure 3). A number of detailed investigations, both on cell culture-based in vitro and preclinical in vivo animal models, underlined the high value of this antiviral approach (reviewed in $[25,53,132,179])$. Thus far, however, with the exception of maribavir, none of these compounds has progressed to clinical studies.
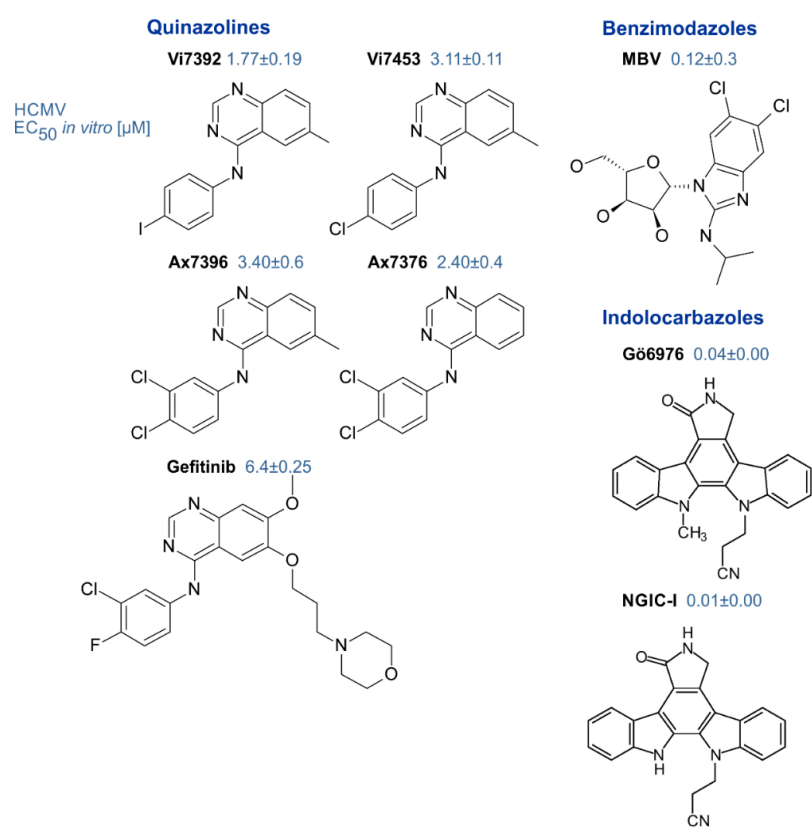

Figure 3. Small molecules derived from different chemical classes possessing strong anti-HCMV efficacy based on their pUL97-inhibitory potential [44,64,109,123,175,178]. 


\section{Clinical Investigation of the First Prototype of a Kinase Inhibitor in Antiviral Treatment: Maribavir}

MBV is a benzimidazole riboside, structurally related to the terminase inhibitors BDCRB and GW275175X [25]. This molecule exerts outstanding inhibitory activity against the pUL97 kinase and shows very low levels of side/off-target effects [180]. MBV exhibits favorable pharmacokinetic properties, is well tolerated and holds promise as a new drug for the treatment of HCMV infections [181-183]. Thus, MBV represents a novel developmental drug that might become the first prototype of a kinase inhibitor in antiviral treatment. In the first phase III clinical study, maribavir-treated patients failed to meet the clinical endpoint objectives [184]. Currently further phase III trials are enrolling patients to compare the efficacy of MBV with GCV, and this clinical development is currently continuing (NCT02931539, NCT02927067). One limitation might be based on the fact that the inhibition of pUL97 kinase activity by MBV interferes with the activation of GCV, thus resulting in drug antagonism, which most probably reduces their antiviral efficacies in a combination therapy $[124,185,186]$. Mutations conferring MBV resistance are distinct from those conferring GCV resistance, with sites of mutations partly located outside the conserved kinase domains [114,132,187]. In rare cases, kinase domain mutations arise in the laboratory that are essentially kinase null mutations and can confer resistance to MBV or GCV [179]. Notably, however, MBV exerts activity against typical GCV-resistant strains and might therefore create new options in the treatment of drug-resistant HCMV infections [175,188,189]. Interestingly, the three different isoforms of the kinase also show altered susceptibility of the virus to MBV [44]. An additional type of an intermediate-level MBV-resistance has been identified for viral variants carrying mutations, not in the UL97 but rather in the UL27 gene [190,191]. To date, it is not clear whether resistance mutations in UL27 would arise in clinical settings, since in animals the deletion of ORF-UL27 resulted in a modest half-log reduction in viral in vitro replication capacity, with no apparent effect on replication in vivo [192].

\section{The Relevance of Targeting a Herpesviral Kinase Activity in Antiviral Strategies}

The HCMV-encoded kinase pUL97 combines two different aspects of medical importance, namely serving as promoter of prodrug activation through the activating monophosphorylation of GCV, VGCV and related nucleoside analogs and as a validated target of antiviral kinase inhibitors. The currently ongoing clinical investigations of MBV are approaching an exciting interim phase and it will be highly relevant to see whether this drug candidate achieves primary endpoints. MBV might not only represent a novel drug for the treatment and prevention of HCMV disease but it would likewise be a very promising novel prototype of a kinase inhibitor that might—compared to the numerous currently approved kinase inhibitors in antitumoral treatments-for the first time enter the field of antiviral therapy. Notably, the applicability of a further mode of action of antiviral drugs would directly broaden the options of overcoming previous problems with antiviral drug resistance. The pharmacological interference with viral kinase activity/protein phosphorylation by MBV, in addition to the targeting of viral genome replication/polymerase activity (GCV) and viral terminase activity/genome processing (LMV), would open a third mechanistic option of HCMV treatment. Thus, resistant mutants arising from GCV and LMV treatment would very probably remain susceptible to MBV treatment, so that variable regimens might become available, possibly including combination therapies. It should be mentioned, however, that GCV and MBV combination would underlie an antagonistic principle, due to the two counteractive roles of pUL97 in such a case (prodrug converting GCV phosphorylation through active pUL97 versus an inhibition of pUL97 activity by MBV). Nevertheless, other combinations between MBV and LMV, GCV and LMV or the involvement of additional approved anti-herpesviral drugs, such as CDV, ACV etc., might lead to a substantial improvement of medication regimens. In this sense, anti-HCMV therapy might also greatly benefit from the experiences made in the field of human immunodeficiency virus/AIDS during the past decades, as mostly gathered by the steady development of novel antiretroviral combination therapies. 


\section{Future Perspectives of Novel Mechanistic Options of pUL97-Specific Drug Targeting}

It should also be stressed that the drug targeting of a viral kinase such as pUL97 may not exclusively be limited to classical ATP-competitive types of kinase inhibitors including MBV. This strategy entails also untypical, thus far therapeutically untapped possibilities of kinase targeting, i.e., non-ATP-competitive modes of targeting [193-195]. It is quite conceivable that additional research work may reveal prototypes of non-ATP-competitive substrate inhibitors of pUL97 that could be directed to blocking the phosphorylation of individual pUL97 substrates, without inactivating the functionality of the pUL97 kinase domain. Such types of kinase inhibitory small molecules can either function through a shielding mechanism directed at one or several defined phosphorylation sites of a pUL97 substrate (phosphosite inhibitors) or it might cause a steric hindrance of pUL97 substrate recognition (allosteric assembly blockers of kinase-specific protein complexes, including an interference with pUL97-cyclin association [56,196,197]). Even the involvement of covalent binders appears within the realms of possibility. Recently, remarkable progress has been reported in the field of generating small molecules acting as covalent kinase binders with selectivity to the tumor-relevant mutant G12C of the human KRAS tyrosine kinase [198]. The kinase inhibitor AMG510 has recently been successfully investigated in clinical stage I/II [199]. Combined, the increase in understanding of the individual molecular features and the overall functionality of pUL97, together with the development of a number of highly interesting and innovative small molecule-type kinase inhibitors, nourishes the long-held optimism about translational success with pUL97 inhibitors in the near future. Thus, one of the experimentally and pharmacologically approved inhibitors, such as maribavir or, alternatively, cancer-approved CDK inhibitors, represent the first candidates of kinase inhibitor to be clinically applied in antiviral therapy.

Supplementary Materials: The following are available online at http://www.mdpi.com/2076-2607/8/4/515/s1.

Acknowledgments: The authors greatly acknowledge the creative and productive long-term cooperations with William D. Rawlinson and collaborators (Virology, UNSW, Sydney, AU), Yohann Coute and the EDyP team (Proteomics Center, Univ. Grenoble, France), Sunwen Chou (OHSU, Portland, OR, USA), Heinrich Sticht (Bioinformatics, Erlangen-Nürnberg, Germany), Peter Lischka (AiCuris Anti-Infective Cures GmbH, Wuppertal, Germany), Thomas Stamminger (Virology, Univ. Ulm, Germany) and all present and previous members of the M.M. laboratory. Many thanks for the highly competent and stimulating contributions to the individual project lines of our pUL97 kinase research. The projects were supported by the Deutsche Forschungsgemeinschaft (grants SFB796/C3, MA1289/8-1), DAAD-Go8 (grants 2017-18/MM-WDR, 2020-21/MM-WDR), Wilhelm Sander-Stiftung (grants 2011.085.1-2, 2018.121.1) and Bayerische Forschungsstiftung (grants ForBiMed/I1, DeeP-CMV/AP-E). This article is dedicated to our highly esteemed scientific partner and friendly connected colleague Mark Prichard (Virology, UAB, Birmingham AL, USA; Editor Antiviral Res.; † June 13, 2019).

Conflicts of Interest: The authors declare no conflict of interest.

\section{References}

1. Lachmann, R.; Loenenbach, A.; Waterboer, T.; Brenner, N.; Pawlita, M.; Michel, A.; Thamm, M.; Poethko-Muller, C.; Wichmann, O.; Wiese-Posselt, M. Cytomegalovirus (CMV) seroprevalence in the adult population of Germany. PLoS ONE 2018, 13, e0200267. [CrossRef] [PubMed]

2. Mocarski, E.S.; Shenk, T.; Griffiths, P.D.; Pass, R.F. Cytomegaloviruses. In Fields Virology, 6th ed.; Knipe, D.M., Howley, P.M., Eds.; Lippincott Williams \& Wilkins: Philadelphia, PA, USA, 2013; Volume 2, pp. 1960-2014.

3. Roizman, B.; Knipe, D.M. Herpesviruses and Their Replication; Knipe, D.M., Howley, P.M., Eds.; Lippincott Williams \& Wilkins: Philadelphia, PA, USA, 2001; pp. 2399-2460.

4. Stinski, M.F. Molecular Biology of Cytomegaloviruses. In The Herpesviruses; Viruses, B.R., Ed.; Springer: Boston, MA, USA, 1983; pp. 67-113.

5. Lee, C.P.; Chen, M.R. Escape of herpesviruses from the nucleus. Rev. Med. Virol. 2010, 20, 214-230. [CrossRef] [PubMed]

6. Das, S.; Vasanji, A.; Pellett, P.E. Three-dimensional structure of the human cytomegalovirus cytoplasmic virion assembly complex includes a reoriented secretory apparatus. J. Virol. 2007, 81, 11861-11869. [CrossRef] 
7. Sanchez, V.; Greis, K.D.; Sztul, E.; Britt, W.J. Accumulation of virion tegument and envelope proteins in a stable cytoplasmic compartment during human cytomegalovirus replication: Characterization of a potential site of virus assembly. J. Virol. 2000, 74, 975-986. [CrossRef]

8. Plachter, B.; Sinzger, C.; Jahn, G. Cell types involved in replication and distribution of human cytomegalovirus. Adv. Virus Res. 1996, 46, 195-261.

9. Sinzger, C.; Digel, M.; Jahn, G. Cytomegalovirus cell tropism. Curr. Top. Microbiol. Immunol. 2008, 325, 63-83. [PubMed]

10. Sinzger, C.; Grefte, A.; Plachter, B.; Gouw, A.S.; The, T.H.; Jahn, G. Fibroblasts, epithelial cells, endothelial cells and smooth muscle cells are major targets of human cytomegalovirus infection in lung and gastrointestinal tissues. J. Gen. Virol. 1995, 76, 741-750. [CrossRef] [PubMed]

11. Weng, C.; Lee, D.; Gelbmann, C.B.; Van Sciver, N.; Nawandar, D.M.; Kenney, S.C.; Kalejta, R.F. Human Cytomegalovirus Productively Replicates In Vitro in Undifferentiated Oral Epithelial Cells. J. Virol. 2018, 92, e00903-18. [CrossRef] [PubMed]

12. Scrivano, L.; Sinzger, C.; Nitschko, H.; Koszinowski, U.H.; Adler, B. HCMV spread and cell tropism are determined by distinct virus populations. PLoS Pathog. 2011, 7, e1001256. [CrossRef]

13. Collins-McMillen, D.; Buehler, J.; Peppenelli, M.; Goodrum, F. Molecular Determinants and the Regulation of Human Cytomegalovirus Latency and Reactivation. Viruses 2018, 10, 44. [CrossRef]

14. Boeckh, M.; Nichols, W.G.; Papanicolaou, G.; Rubin, R.; Wingard, J.R.; Zaia, J. Cytomegalovirus in hematopoietic stem cell transplant recipients: Current status, known challenges, and future strategies. Biol. Blood Marrow Transplant. 2003, 9, 543-558. [CrossRef]

15. Rafailidis, P.I.; Mourtzoukou, E.G.; Varbobitis, I.C.; Falagas, M.E. Severe cytomegalovirus infection in apparently immunocompetent patients: A systematic review. Virol. J. 2008, 5, 47. [CrossRef] [PubMed]

16. Steininger, C. Clinical relevance of cytomegalovirus infection in patients with disorders of the immune system. Clin. Microbiol. Infect. 2007, 13, 953-963. [CrossRef] [PubMed]

17. Wolf, D.G.; Lurain, N.S.; Zuckerman, T.; Hoffman, R.; Satinger, J.; Honigman, A.; Saleh, N.; Robert, E.S.; Rowe, J.M.; Kra-Oz, Z. Emergence of late cytomegalovirus central nervous system disease in hematopoietic stem cell transplant recipients. Blood 2003, 101, 463-465. [CrossRef]

18. Britt, W.J. Congenital Human Cytomegalovirus Infection and the Enigma of Maternal Immunity. J. Virol. 2017, 91, e02392-16. [CrossRef]

19. Buxmann, H.; Hamprecht, K.; Meyer-Wittkopf, M.; Friese, K. Primary Human Cytomegalovirus (HCMV) Infection in Pregnancy. Dtsch. Arztebl. Int. 2017, 114, 45-52. [CrossRef]

20. Crough, T.; Khanna, R. Immunobiology of human cytomegalovirus: From bench to bedside. Clin. Microbiol. Rev. 2009, 22, 76-98. [CrossRef]

21. Hamilton, S.T.; van Zuylen, W.; Shand, A.; Scott, G.M.; Naing, Z.; Hall, B.; Craig, M.E.; Rawlinson, W.D. Prevention of congenital cytomegalovirus complications by maternal and neonatal treatments: A systematic review. Rev. Med. Virol. 2014, 24, 420-433. [CrossRef]

22. Revello, M.G.; Gerna, G. Human cytomegalovirus tropism for endothelial/epithelial cells: Scientific background and clinical implications. Rev. Med. Virol. 2010, 20, 136-155. [CrossRef]

23. Sia, I.G.; Patel, R. New strategies for prevention and therapy of cytomegalovirus infection and disease in solid-organ transplant recipients. Clin. Microbiol. Rev. 2000, 13, 83-121. [CrossRef]

24. Tsutsui, Y. Effects of cytomegalovirus infection on embryogenesis and brain development. Congenit. Anom. 2009, 49, 47-55. [CrossRef] [PubMed]

25. Britt, W.J.; Prichard, M.N. New therapies for human cytomegalovirus infections. Antivir. Res. 2018, 159, 153-174. [CrossRef] [PubMed]

26. Kenneson, A.; Cannon, M.J. Review and meta-analysis of the epidemiology of congenital cytomegalovirus (CMV) infection. Rev. Med. Virol. 2007, 17, 253-276. [CrossRef]

27. Craig, J.M.; Macauley, J.C.; Weller, T.H.; Wirth, P. Isolation of intranuclear inclusion producing agents from infants with illnesses resembling cytomegalic inclusion disease. Proc. Soc. Exp. Biol. Med. 1957, 94, 4-12. [PubMed]

28. Riley, H.D., Jr. History of the cytomegalovirus. South. Med. J. 1997, 90, 184-190. [CrossRef] [PubMed]

29. Rowe, W.P.; Hartley, J.W.; Cramblett, H.G.; Mastrota, F.M. Detection of human salivary gland virus in the mouth and urine of children. Am. J. Hyg. 1958, 67, 57-65. 
30. Rowe, W.P.; Hartley, J.W.; Waterman, S.; Turner, H.C.; Huebner, R.J. Cytopathogenic agent resembling human salivary gland virus recovered from tissue cultures of human adenoids. Proc. Soc. Exp. Biol. Med. 1956, 92, 418-424.

31. Smith, M.G. Propagation in tissue cultures of a cytopathogenic virus from human salivary gland virus (SGV) disease. Proc. Soc. Exp. Biol. Med. 1956, 92, 424-430. [CrossRef]

32. Biron, K.K. Antiviral drugs for cytomegalovirus diseases. Antivir. Res. 2006, 71, 154-163. [CrossRef] [PubMed]

33. Boivin, G.; Goyette, N.; Gilbert, C.; Humar, A.; Covington, E. Clinical impact of ganciclovir-resistant cytomegalovirus infections in solid organ transplant patients. Transplant. Infect. Dis. 2005, 7, 166-170. [CrossRef]

34. Danziger-Isakov, L.; Mark Baillie, G. Hematologic complications of anti-CMV therapy in solid organ transplant recipients. Clin. Transplant. 2009, 23, 295-304. [CrossRef] [PubMed]

35. Härter, G.; Michel, D. Antiviral treatment of cytomegalovirus infection: An update. Expert Opin. Pharmacother. 2012, 13, 623-627. [CrossRef] [PubMed]

36. Lischka, P.; Zimmermann, H. Antiviral strategies to combat cytomegalovirus infections in transplant recipients. Curr. Opin. Pharmacol. 2008, 8, 541-548. [CrossRef]

37. Shmueli, E.; Or, R.; Shapira, M.Y.; Resnick, I.B.; Caplan, O.; Bdolah-Abram, T.; Wolf, D.G. High rate of cytomegalovirus drug resistance among patients receiving preemptive antiviral treatment after haploidentical stem cell transplantation. J. Infect. Dis. 2014, 209, 557-561. [CrossRef]

38. Chong, P.P.; Teiber, D.; Prokesch, B.C.; Arasaratnam, R.J.; Peltz, M.; Drazner, M.H.; Garg, S. Letermovir successfully used for secondary prophylaxis in a heart transplant recipient with ganciclovir-resistant cytomegalovirus syndrome (UL97 mutation). Transplant. Infect. Dis. 2018, 20, e12965. [CrossRef]

39. Goldner, T.; Hewlett, G.; Ettischer, N.; Ruebsamen-Schaeff, H.; Zimmermann, H.; Lischka, P. The novel anticytomegalovirus compound AIC246 (Letermovir) inhibits human cytomegalovirus replication through a specific antiviral mechanism that involves the viral terminase. J. Virol. 2011, 85, 10884-10893. [CrossRef]

40. Lischka, P.; Hewlett, G.; Wunberg, T.; Baumeister, J.; Paulsen, D.; Goldner, T.; Ruebsamen-Schaeff, H.; Zimmermann, H. In vitro and in vivo activities of the novel anticytomegalovirus compound AIC246. Antimicrob. Agents Chemother. 2010, 54, 1290-1297. [CrossRef]

41. Wildum, S.; Zimmermann, H.; Lischka, P. In vitro drug combination studies of Letermovir (AIC246, MK-8228) with approved anti-human cytomegalovirus (HCMV) and anti-HIV compounds in inhibition of HCMV and HIV replication. Antimicrob. Agents Chemother. 2015, 59, 3140-3148. [CrossRef]

42. Cherrier, L.; Nasar, A.; Goodlet, K.J.; Nailor, M.D.; Tokman, S.; Chou, S. Emergence of letermovir resistance in a lung transplant recipient with ganciclovir-resistant cytomegalovirus infection. Am. J. Transplant. 2018, 18, 3060-3064. [CrossRef]

43. van Zeijl, M.; Fairhurst, J.; Baum, E.Z.; Sun, L.; Jones, T.R. The human cytomegalovirus UL97 protein is phosphorylated and a component of virions. Virology 1997, 231, 72-80. [CrossRef]

44. Webel, R.; Hakki, M.; Prichard, M.N.; Rawlinson, W.D.; Marschall, M.; Chou, S. Differential properties of cytomegalovirus pUL97 kinase isoforms affect viral replication and maribavir susceptibility. J. Virol. 2014, 88, 4776-4785. [CrossRef] [PubMed]

45. Webel, R.; Milbradt, J.; Auerochs, S.; Schregel, V.; Held, C.; Nobauer, K.; Razzazi-Fazeli, E.; Jardin, C.; Wittenberg, T.; Sticht, H.; et al. Two isoforms of the protein kinase pUL97 of human cytomegalovirus are differentially regulated in their nuclear translocation. J. Gen. Virol. 2011, 92, 638-649. [CrossRef] [PubMed]

46. Webel, R.; Solbak, S.M.; Held, C.; Milbradt, J.; Gross, A.; Eichler, J.; Wittenberg, T.; Jardin, C.; Sticht, H.; Fossen, T.; et al. Nuclear import of isoforms of the cytomegalovirus kinase pUL97 is mediated by differential activity of NLS1 and NLS2 both acting through classical importin-alpha binding. J. Gen. Virol. 2012, 93, 1756-1768. [CrossRef]

47. Steingruber, M.; Socher, E.; Hutterer, C.; Webel, R.; Bergbrede, T.; Lenac, T.; Sticht, H.; Marschall, M. The Interaction between Cyclin B1 and Cytomegalovirus Protein Kinase pUL97 is Determined by an Active Kinase Domain. Viruses 2015, 7, 4582-4601. [CrossRef] [PubMed]

48. Hume, A.J.; Kalejta, R.F. Regulation of the retinoblastoma proteins by the human herpesviruses. Cell Div. 2009, 4, 1. [CrossRef] [PubMed]

49. Gershburg, E.; Pagano, J.S. Conserved herpesvirus protein kinases. Biochim. Biophys. Acta 2008, 1784, $203-212$. [CrossRef] [PubMed] 
50. Michel, D.; Mertens, T. The UL97 protein kinase of human cytomegalovirus and homologues in other herpesviruses: Impact on virus and host. Biochim. Biophys. Acta 2004, 1697, 169-180. [CrossRef]

51. Marschall, M.; Stein-Gerlach, M.; Freitag, M.; Kupfer, R.; van Den Bogaard, M.; Stamminger, T. Inhibitors of human cytomegalovirus replication drastically reduce the activity of the viral protein kinase pUL97. J. Gen. Virol. 2001, 82, 1439-1450. [CrossRef]

52. Prichard, M.N. Function of human cytomegalovirus UL97 kinase in viral infection and its inhibition by maribavir. Rev. Med. Virol. 2009, 19, 215-229. [CrossRef]

53. Marschall, M.; Feichtinger, S.; Milbradt, J. Regulatory roles of protein kinases in cytomegalovirus replication. Adv. Virus Res. 2011, 80, 69-101.

54. Schregel, V.; Auerochs, S.; Jochmann, R.; Maurer, K.; Stamminger, T.; Marschall, M. Mapping of a self-interaction domain of the cytomegalovirus protein kinase pUL97. J. Gen. Virol. 2007, 88, 395-404. [CrossRef] [PubMed]

55. Graf, L.; Webel, R.; Wagner, S.; Hamilton, S.T.; Rawlinson, W.D.; Sticht, H.; Marschall, M. The cyclin-dependent kinase ortholog pUL97 of human cytomegalovirus interacts with cyclins. Viruses 2013, 5, 3213-3230. [CrossRef] [PubMed]

56. Steingruber, M.; Keller, L.; Socher, E.; Ferre, S.; Hesse, A.M.; Coute, Y.; Hahn, F.; Büscher, N.; Plachter, B.; Sticht, H.; et al. Cyclins B1, T1, and H differ in their molecular mode of interaction with cytomegalovirus protein kinase pUL97. J. Biol. Chem. 2019, 294, 6188-6203. [CrossRef] [PubMed]

57. Kuny, C.V.; Chinchilla, K.; Culbertson, M.R.; Kalejta, R.F. Cyclin-dependent kinase-like function is shared by the beta- and gamma-subset of the conserved herpesvirus protein kinases. PLoS Pathog. 2010, 6, e1001092. [CrossRef] [PubMed]

58. Hertel, L.; Chou, S.; Mocarski, E.S. Viral and cell cycle-regulated kinases in cytomegalovirus-induced pseudomitosis and replication. PLoS Pathog. 2007, 3, e6. [CrossRef]

59. Wolf, D.G.; Courcelle, C.T.; Prichard, M.N.; Mocarski, E.S. Distinct and separate roles for herpesvirus-conserved UL97 kinase in cytomegalovirus DNA synthesis and encapsidation. Proc. Natl. Acad. Sci. USA 2001, 98, 1895-1900. [CrossRef]

60. Prichard, M.N.; Britt, W.J.; Daily, S.L.; Hartline, C.B.; Kern, E.R. Human cytomegalovirus UL97 Kinase is required for the normal intranuclear distribution of pp65 and virion morphogenesis. J. Virol. 2005, 79, 15494-15502. [CrossRef]

61. Prichard, M.N.; Gao, N.; Jairath, S.; Mulamba, G.; Krosky, P.; Coen, D.M.; Parker, B.O.; Pari, G.S. A recombinant human cytomegalovirus with a large deletion in UL97 has a severe replication deficiency. J. Virol. 1999, 73, 5663-5670. [CrossRef]

62. Marschall, M.; Muller, Y.A.; Diewald, B.; Sticht, H.; Milbradt, J. The human cytomegalovirus nuclear egress complex unites multiple functions: Recruitment of effectors, nuclear envelope rearrangement, and docking to nuclear capsids. Rev. Med. Virol. 2017, 27, e1934. [CrossRef]

63. Romaker, D.; Schregel, V.; Maurer, K.; Auerochs, S.; Marzi, A.; Sticht, H.; Marschall, M. Analysis of the structure-activity relationship of four herpesviral UL97 subfamily protein kinases reveals partial but not full functional conservation. J. Med. Chem. 2006, 49, 7044-7053. [CrossRef]

64. Hutterer, C.; Hamilton, S.; Steingruber, M.; Zeittrager, I.; Bahsi, H.; Thuma, N.; Naing, Z.; Orfi, Z.; Orfi, L.; Socher, E.; et al. The chemical class of quinazoline compounds provides a core structure for the design of anticytomegaloviral kinase inhibitors. Antivir. Res. 2016, 134, 130-143. [CrossRef] [PubMed]

65. Baek, M.C.; Krosky, P.M.; Coen, D.M. Relationship between autophosphorylation and phosphorylation of exogenous substrates by the human cytomegalovirus UL97 protein kinase. J. Virol. 2002, 76, 11943-11952. [CrossRef] [PubMed]

66. Oberstein, A.; Perlman, D.H.; Shenk, T.; Terry, L.J. Human cytomegalovirus pUL97 kinase induces global changes in the infected cell phosphoproteome. Proteomics 2015, 15, 2006-2022. [CrossRef]

67. Michel, D.; Pavic, I.; Zimmermann, A.; Haupt, E.; Wunderlich, K.; Heuschmid, M.; Mertens, T. The UL97 gene product of human cytomegalovirus is an early-late protein with a nuclear localization but is not a nucleoside kinase. J. Virol. 1996, 70, 6340-6346. [CrossRef] [PubMed]

68. Littler, E.; Stuart, A.D.; Chee, M.S. Human cytomegalovirus UL97 open reading frame encodes a protein that phosphorylates the antiviral nucleoside analogue ganciclovir. Nature 1992, 358, 160-162. [CrossRef] 
69. Sullivan, V.; Talarico, C.L.; Stanat, S.C.; Davis, M.; Coen, D.M.; Biron, K.K. A protein kinase homologue controls phosphorylation of ganciclovir in human cytomegalovirus-infected cells. Nature 1992, $359,85$. [CrossRef]

70. Held, C.; Webel, R.; Palmisano, R.; Hutterer, C.; Marschall, M.; Wittenberg, T. Using multi-channel level sets to measure the cytoplasmic localization of HCMV pUL97 in GFP-B-gal fusion constructs. J. Virol. Methods 2014, 199, 61-67. [CrossRef]

71. Lee, S.H.; Caviness, K.; Albright, E.R.; Lee, J.H.; Gelbmann, C.B.; Rak, M.; Goodrum, F.; Kalejta, R.F. Long and Short Isoforms of the Human Cytomegalovirus UL138 Protein Silence IE Transcription and Promote Latency. J. Virol. 2016, 90, 9483-9494. [CrossRef]

72. Chou, S.; Ercolani, R.J.; Derakhchan, K. Antiviral activity of maribavir in combination with other drugs active against human cytomegalovirus. Antivir. Res. 2018, 157, 128-133. [CrossRef]

73. Caviness, K.; Bughio, F.; Crawford, L.B.; Streblow, D.N.; Nelson, J.A.; Caposio, P.; Goodrum, F. Complex Interplay of the UL136 Isoforms Balances Cytomegalovirus Replication and Latency. mBio 2016, 7, e01986. [CrossRef]

74. Sehl, J.; Portner, S.; Klupp, B.G.; Granzow, H.; Franzke, K.; Teifke, J.P.; Mettenleiter, T.C. Roles of the different isoforms of the pseudorabies virus protein kinase pUS3 in nuclear egress. J. Virol. 2020. [CrossRef] [PubMed]

75. Hume, A.J.; Finkel, J.S.; Kamil, J.P.; Coen, D.M.; Culbertson, M.R.; Kalejta, R.F. Phosphorylation of retinoblastoma protein by viral protein with cyclin-dependent kinase function. Science 2008, 320, 797-799. [CrossRef]

76. Cunningham, C.; Gatherer, D.; Hilfrich, B.; Baluchova, K.; Dargan, D.J.; Thomson, M.; Griffiths, P.D.; Wilkinson, G.W.; Schulz, T.F.; Davison, A.J. Sequences of complete human cytomegalovirus genomes from infected cell cultures and clinical specimens. J. Gen. Virol. 2010, 91, 605-615. [CrossRef] [PubMed]

77. Lurain, N.S.; Weinberg, A.; Crumpacker, C.S.; Chou, S. Sequencing of cytomegalovirus UL97 gene for genotypic antiviral resistance testing. Antimicrob. Agents Chemother. 2001, 45, 2775-2780. [CrossRef] [PubMed]

78. Rechter, S.; Scott, G.M.; Eickhoff, J.; Zielke, K.; Auerochs, S.; Muller, R.; Stamminger, T.; Rawlinson, W.D.; Marschall, M. Cyclin-dependent Kinases Phosphorylate the Cytomegalovirus RNA Export Protein pUL69 and Modulate Its Nuclear Localization and Activity. J. Biol. Chem. 2009, 284, 8605-8613. [CrossRef]

79. Thomas, M.; Rechter, S.; Milbradt, J.; Auerochs, S.; Muller, R.; Stamminger, T.; Marschall, M. Cytomegaloviral protein kinase pUL97 interacts with the nuclear mRNA export factor pUL69 to modulate its intranuclear localization and activity. J. Gen. Virol. 2009, 90, 567-578. [CrossRef]

80. Feichtinger, S.; Stamminger, T.; Muller, R.; Graf, L.; Klebl, B.; Eickhoff, J.; Marschall, M. Recruitment of cyclin-dependent kinase 9 to nuclear compartments during cytomegalovirus late replication: Importance of an interaction between viral pUL69 and cyclin T1. J. Gen. Virol. 2011, 92, 1519-1531. [CrossRef]

81. Graf, L.; Feichtinger, S.; Naing, Z.; Hutterer, C.; Milbradt, J.; Webel, R.; Wagner, S.; Scott, G.M.; Hamilton, S.T.; Rawlinson, W.D.; et al. New insight into the phosphorylation-regulated intranuclear localization of human cytomegalovirus pUL69 mediated by cyclin-dependent kinases (CDKs) and viral CDK orthologue pUL97. J. Gen. Virol. 2016, 97, 144-151. [CrossRef]

82. Steingruber, M.; Kraut, A.; Socher, E.; Sticht, H.; Reichel, A.; Stamminger, T.; Amin, B.; Coute, Y.; Hutterer, C.; Marschall, M. Proteomic Interaction Patterns between Human Cyclins, the Cyclin-Dependent Kinase Ortholog pUL97 and Additional Cytomegalovirus Proteins. Viruses 2016, 8, 219. [CrossRef]

83. König, P.; Buscher, N.; Steingruber, M.; Socher, E.; Sticht, H.; Tenzer, S.; Plachter, B.; Marschall, M. Dynamic regulatory interaction between cytomegalovirus major tegument protein pp65 and protein kinase pUL97 in intracellular compartments, dense bodies and virions. J. Gen. Virol. 2017, 98, 2850-2863. [CrossRef]

84. Hamirally, S.; Kamil, J.P.; Ndassa-Colday, Y.M.; Lin, A.J.; Jahng, W.J.; Baek, M.C.; Noton, S.; Silva, L.A.; Simpson-Holley, M.; Knipe, D.M.; et al. Viral mimicry of Cdc2/cyclin-dependent kinase 1 mediates disruption of nuclear lamina during human cytomegalovirus nuclear egress. PLoS Pathog. 2009, 5, e1000275. [CrossRef] [PubMed]

85. Kamil, J.P.; Hume, A.J.; Jurak, I.; Munger, K.; Kalejta, R.F.; Coen, D.M. Human papillomavirus 16 E7 inactivator of retinoblastoma family proteins complements human cytomegalovirus lacking UL97 protein kinase. Proc. Natl. Acad. Sci. USA 2009, 106, 16823-16828. [CrossRef] [PubMed] 
86. Hutterer, C.; Wandinger, S.K.; Wagner, S.; Muller, R.; Stamminger, T.; Zeittrager, I.; Godl, K.; Baumgartner, R.; Strobl, S.; Marschall, M. Profiling of the kinome of cytomegalovirus-infected cells reveals the functional importance of host kinases Aurora A, ABL and AMPK. Antivir. Res. 2013, 99, 139-148. [CrossRef] [PubMed]

87. Milbradt, J.; Auerochs, S.; Sevvana, M.; Muller, Y.A.; Sticht, H.; Marschall, M. Specific residues of a conserved domain in the $\mathrm{N}$ terminus of the human cytomegalovirus pUL50 protein determine its intranuclear interaction with pUL53. J. Biol. Chem. 2012, 287, 24004-24016. [CrossRef] [PubMed]

88. Gill, R.B.; James, S.H.; Prichard, M.N. Human cytomegalovirus UL97 kinase alters the accumulation of CDK1. J. Gen. Virol. 2012, 93, 1743-1755. [CrossRef] [PubMed]

89. Jault, F.M.; Jault, J.M.; Ruchti, F.; Fortunato, E.A.; Clark, C.; Corbeil, J.; Richman, D.D.; Spector, D.H. Cytomegalovirus infection induces high levels of cyclins, phosphorylated $\mathrm{Rb}$, and p53, leading to cell cycle arrest. J. Virol. 1995, 69, 6697-6704. [CrossRef]

90. Kapasi, A.J.; Spector, D.H. Inhibition of the cyclin-dependent kinases at the beginning of human cytomegalovirus infection specifically alters the levels and localization of the RNA polymerase II carboxyl-terminal domain kinases cdk9 and cdk7 at the viral transcriptosome. J. Virol. 2008, 82, $394-407$. [CrossRef]

91. Sanchez, V.; McElroy, A.K.; Spector, D.H. Mechanisms governing maintenance of Cdk1/cyclin B1 kinase activity in cells infected with human cytomegalovirus. J. Virol. 2003, 77, 13214-13224. [CrossRef]

92. Spector, D.H. Human cytomegalovirus riding the cell cycle. Med. Microbiol. Immunol. 2015, 204, 409-419. [CrossRef]

93. Tamrakar, S.; Kapasi, A.J.; Spector, D.H. Human cytomegalovirus infection induces specific hyperphosphorylation of the carboxyl-terminal domain of the large subunit of RNA polymerase II that is associated with changes in the abundance, activity, and localization of cdk9 and cdk7. J. Virol. 2005, 79, 15477-15493. [CrossRef]

94. Marschall, M.; Marzi, A.; aus dem Siepen, P.; Jochmann, R.; Kalmer, M.; Auerochs, S.; Lischka, P.; Leis, M.; Stamminger, T. Cellular p32 recruits cytomegalovirus kinase pUL97 to redistribute the nuclear lamina. J. Biol. Chem. 2005, 280, 33357-33367. [CrossRef]

95. Becke, S.; Fabre-Mersseman, V.; Aue, S.; Auerochs, S.; Sedmak, T.; Wolfrum, U.; Strand, D.; Marschall, M.; Plachter, B.; Reyda, S. Modification of the major tegument protein pp65 of human cytomegalovirus inhibits virus growth and leads to the enhancement of a protein complex with pUL69 and pUL97 in infected cells. J. Gen. Virol. 2010, 91, 2531-2541. [CrossRef]

96. Dell'Oste, V.; Gatti, D.; Gugliesi, F.; De Andrea, M.; Bawadekar, M.; Lo Cigno, I.; Biolatti, M.; Vallino, M.; Marschall, M.; Gariglio, M.; et al. Innate nuclear sensor IFI16 translocates into the cytoplasm during the early stage of in vitro human cytomegalovirus infection and is entrapped in the egressing virions during the late stage. J. Virol. 2014, 88, 6970-6982. [CrossRef]

97. Milbradt, J.; Hutterer, C.; Bahsi, H.; Wagner, S.; Sonntag, E.; Horn, A.H.; Kaufer, B.B.; Mori, Y.; Sticht, H.; Fossen, T.; et al. The Prolyl Isomerase Pin1 Promotes the Herpesvirus-Induced Phosphorylation-Dependent Disassembly of the Nuclear Lamina Required for Nucleocytoplasmic Egress. PLoS Pathog. 2016, 12, e1005825. [CrossRef]

98. Milbradt, J.; Kraut, A.; Hutterer, C.; Sonntag, E.; Schmeiser, C.; Ferro, M.; Wagner, S.; Lenac, T.; Claus, C.; Pinkert, S.; et al. Proteomic analysis of the multimeric nuclear egress complex of human cytomegalovirus. Mol. Cell Proteom. 2014, 13, 2132-2146. [CrossRef]

99. Sharma, M.; Bender, B.J.; Kamil, J.P.; Lye, M.F.; Pesola, J.M.; Reim, N.I.; Hogle, J.M.; Coen, D.M. Human cytomegalovirus UL97 phosphorylates the viral nuclear egress complex. J. Virol. 2015, 89, 523-534. [CrossRef]

100. Baek, M.C.; Krosky, P.M.; Pearson, A.; Coen, D.M. Phosphorylation of the RNA polymerase II carboxyl-terminal domain in human cytomegalovirus-infected cells and in vitro by the viral UL97 protein kinase. Virology 2004, 324, 184-193. [CrossRef]

101. Kawaguchi, Y.; Matsumura, T.; Roizman, B.; Hirai, K. Cellular elongation factor 1delta is modified in cells infected with representative alpha-, beta-, or gammaherpesviruses. J. Virol. 1999, 73, 4456-4460. [CrossRef]

102. Bigley, T.M.; Reitsma, J.M.; Mirza, S.P.; Terhune, S.S. Human cytomegalovirus pUL97 regulates the viral major immediate early promoter by phosphorylation-mediated disruption of histone deacetylase 1 binding. J. Virol. 2013, 87, 7393-7408. [CrossRef] 
103. Iwahori, S.; Umana, A.C.; VanDeusen, H.R.; Kalejta, R.F. Human cytomegalovirus-encoded viral cyclin-dependent kinase (v-CDK) UL97 phosphorylates and inactivates the retinoblastoma protein-related p107 and p130 proteins. J. Biol. Chem. 2017, 292, 6583-6599. [CrossRef]

104. Krosky, P.M.; Baek, M.C.; Jahng, W.J.; Barrera, I.; Harvey, R.J.; Biron, K.K.; Coen, D.M.; Sethna, P.B. The human cytomegalovirus UL44 protein is a substrate for the UL97 protein kinase. J. Virol. 2003, 77, 7720-7727. [CrossRef] [PubMed]

105. Businger, R.; Deutschmann, J.; Gruska, I.; Milbradt, J.; Wiebusch, L.; Gramberg, T.; Schindler, M. Human cytomegalovirus overcomes SAMHD1 restriction in macrophages via pUL97. Nat. Microbiol. 2019, 4, 2260-2272. [CrossRef] [PubMed]

106. Iwahori, S.; Kalejta, R.F. Phosphorylation of transcriptional regulators in the retinoblastoma protein pathway by UL97, the viral cyclin-dependent kinase encoded by human cytomegalovirus. Virology 2017, 512, 95-103. [CrossRef]

107. Biolatti, M.; Dell'Oste, V.; Pautasso, S.; von Einem, J.; Marschall, M.; Plachter, B.; Gariglio, M.; De Andrea, M.; Landolfo, S. Regulatory Interaction between the Cellular Restriction Factor IFI16 and Viral pp65 (pUL83) Modulates Viral Gene Expression and IFI16 Protein Stability. J. Virol. 2016, 90, 8238-8250. [CrossRef]

108. Landolfo, S.; De Andrea, M.; Dell'Oste, V.; Gugliesi, F. Intrinsic host restriction factors of human cytomegalovirus replication and mechanisms of viral escape. World J. Virol. 2016, 5, 87-96. [CrossRef]

109. Marschall, M.; Stein-Gerlach, M.; Freitag, M.; Kupfer, R.; van den Bogaard, M.; Stamminger, T. Direct targeting of human cytomegalovirus protein kinase pUL97 by kinase inhibitors is a novel principle for antiviral therapy. J. Gen. Virol. 2002, 83, 1013-1023. [CrossRef]

110. He, Z.; He, Y.S.; Kim, Y.; Chu, L.; Ohmstede, C.; Biron, K.K.; Coen, D.M. The human cytomegalovirus UL97 protein is a protein kinase that autophosphorylates on serines and threonines. J. Virol. 1997, 71, 405-411. [CrossRef]

111. Mett, H.; Holscher, K.; Degen, H.; Esdar, C.; De Neumann, B.F.; Flicke, B.; Freudenreich, T.; Holzer, G.; Schinzel, S.; Stamminger, T; et al. Identification of inhibitors for a virally encoded protein kinase by 2 different screening systems: In vitro kinase assay and in-cell activity assay. J. Biomol. Screen. 2005, 10, 36-45. [CrossRef]

112. Zimmermann, A.; Michel, D.; Pavic, I.; Hampl, W.; Luske, A.; Neyts, J.; De Clercq, E.; Mertens, T. Phosphorylation of aciclovir, ganciclovir, penciclovir and S2242 by the cytomegalovirus UL97 protein: A quantitative analysis using recombinant vaccinia viruses. Antivir. Res. 1997, 36, 35-42. [CrossRef]

113. Talarico, C.L.; Burnette, T.C.; Miller, W.H.; Smith, S.L.; Davis, M.G.; Stanat, S.C.; Ng, T.I.; He, Z.; Coen, D.M.; Roizman, B.; et al. Acyclovir is phosphorylated by the human cytomegalovirus UL97 protein. Antimicrob. Agents Chemother. 1999, 43, 1941-1946. [CrossRef]

114. Chou, S.; Wechel, L.C.; Marousek, G.I. Cytomegalovirus UL97 kinase mutations that confer maribavir resistance. J. Infect. Dis. 2007, 196, 91-94. [CrossRef]

115. Scott, G.M.; Isaacs, M.A.; Zeng, F.; Kesson, A.M.; Rawlinson, W.D. Cytomegalovirus antiviral resistance associated with treatment induced UL97 (protein kinase) and UL54 (DNA polymerase) mutations. J. Med. Virol. 2004, 74, 85-93. [CrossRef]

116. Wolf, D.G.; Honigman, A.; Lazarovits, J.; Tavor, E.; Panet, A. Characterization of the human cytomegalovirus UL97 gene product as a virion-associated protein kinase. Arch. Virol. 1998, 143, 1223-1232. [CrossRef]

117. Chevillotte, M.; Landwehr, S.; Linta, L.; Frascaroli, G.; Luske, A.; Buser, C.; Mertens, T.; von Einem, J. Major tegument protein pp65 of human cytomegalovirus is required for the incorporation of pUL69 and pUL97 into the virus particle and for viral growth in macrophages. J. Virol. 2009, 83, 2480-2490. [CrossRef]

118. Milbradt, J.; Sonntag, E.; Wagner, S.; Strojan, H.; Wangen, C.; Lenac Rovis, T.; Lisnic, B.; Jonjic, S.; Sticht, H.; Britt, W.J.; et al. Human Cytomegalovirus Nuclear Capsids Associate with the Core Nuclear Egress Complex and the Viral Protein Kinase pUL97. Viruses 2018, 10, 35. [CrossRef]

119. Herget, T.; Marschall, M. Recent developments in anti-herpesviral combination therapy based on protein kinase inhibitors. In New Concepts of Antiviral Therapy; Springer: Boston, MA, USA, 2006; pp. 351-371.

120. Zimmermann, A.; Wilts, H.; Lenhardt, M.; Hahn, M.; Mertens, T. Indolocarbazoles exhibit strong antiviral activity against human cytomegalovirus and are potent inhibitors of the pUL97 protein kinase. Antivir. Res. 2000, 48, 49-60. [CrossRef]

121. Slater, M.J.; Baxter, R.; Bonser, R.W.; Cockerill, S.; Gohil, K.; Parry, N.; Robinson, E.; Randall, R.; Yeates, C.; Snowden, W; et al. Synthesis of N-alkyl substituted indolocarbazoles as potent inhibitors of human cytomegalovirus replication. Bioorg. Med. Chem. Lett. 2001, 11, 1993-1995. [CrossRef] 
122. Marschall, M.; Freitag, M.; Suchy, P.; Romaker, D.; Kupfer, R.; Hanke, M.; Stamminger, T. The protein kinase pUL97 of human cytomegalovirus interacts with and phosphorylates the DNA polymerase processivity factor pUL44. Virology 2003, 311, 60-71. [CrossRef]

123. Schleiss, M.; Eickhoff, J.; Auerochs, S.; Leis, M.; Abele, S.; Rechter, S.; Choi, Y.; Anderson, J.; Scott, G.; Rawlinson, W.; et al. Protein kinase inhibitors of the quinazoline class exert anti-cytomegaloviral activity in vitro and in vivo. Antivir. Res. 2008, 79, 49-61. [CrossRef]

124. Chou, S.; Marousek, G.I. Maribavir antagonizes the antiviral action of ganciclovir on human cytomegalovirus. Antimicrob. Agents Chemother. 2006, 50, 3470-3472. [CrossRef]

125. Cazorla-Vazquez, S.; Steingruber, M.; Marschall, M.; Engel, F.B. Human cytomegaloviral multifunctional protein kinase pUL97 impairs zebrafish embryonic development and increases mortality. Sci. Rep. 2019, 9, 7219. [CrossRef] [PubMed]

126. Walzer, S.A.; Egerer-Sieber, C.; Sticht, H.; Sevvana, M.; Hohl, K.; Milbradt, J.; Muller, Y.A.; Marschall, M. Crystal Structure of the Human Cytomegalovirus pUL50-pUL53 Core Nuclear Egress Complex Provides Insight into a Unique Assembly Scaffold for Virus-Host Protein Interactions. J. Biol. Chem. 2015, 290, 27452-27458. [CrossRef] [PubMed]

127. Sonntag, E.; Milbradt, J.; Svrlanska, A.; Strojan, H.; Hage, S.; Kraut, A.; Hesse, A.M.; Amin, B.; Sonnewald, U.; Coute, Y.; et al. Protein kinases responsible for the phosphorylation of the nuclear egress core complex of human cytomegalovirus. J. Gen. Virol. 2017, 98, 2569-2581. [CrossRef]

128. Sonntag, E.; Hamilton, S.T.; Bahsi, H.; Wagner, S.; Jonjic, S.; Rawlinson, W.D.; Marschall, M.; Milbradt, J. Erratum to Cytomegalovirus pUL50 is the multi-interacting determinant of the core nuclear egress complex (NEC) that recruits cellular accessory NEC components. J. Gen. Virol. 2016, 97, 2461. [CrossRef]

129. Milbradt, J.; Webel, R.; Auerochs, S.; Sticht, H.; Marschall, M. Novel mode of phosphorylation-triggered reorganization of the nuclear lamina during nuclear egress of human cytomegalovirus. J. Biol. Chem. 2010, 285, 13979-13989. [CrossRef]

130. Kawaguchi, Y.; Kato, K.; Tanaka, M.; Kanamori, M.; Nishiyama, Y.; Yamanashi, Y. Conserved protein kinases encoded by herpesviruses and cellular protein kinase cdc2 target the same phosphorylation site in eukaryotic elongation factor 1delta. J. Virol. 2003, 77, 2359-2368. [CrossRef]

131. Ruiz-Carrascoso, G.; Romero-Gomez, M.P.; Plaza, D.; Mingorance, J. Rapid detection and quantitation of ganciclovir resistance in cytomegalovirus quasispecies. J. Med. Virol. 2013, 85, 1250-1257. [CrossRef]

132. Chou, S. Cytomegalovirus UL97 mutations in the era of ganciclovir and maribavir. Rev. Med. Virol. 2008, 18, 233-246. [CrossRef]

133. Chou, S.; Van Wechel, L.C.; Marousek, G.I. Effect of cell culture conditions on the anticytomegalovirus activity of maribavir. Antimicrob. Agents Chemother. 2006, 50, 2557-2559. [CrossRef]

134. Leigh, K.E.; Sharma, M.; Mansueto, M.S.; Boeszoermenyi, A.; Filman, D.J.; Hogle, J.M.; Wagner, G.; Coen, D.M.; Arthanari, H. Structure of a herpesvirus nuclear egress complex subunit reveals an interaction groove that is essential for viral replication. Proc. Natl. Acad. Sci. USA 2015, 112, 9010-9015. [CrossRef]

135. Lye, M.F.; Sharma, M.; El Omari, K.; Filman, D.J.; Schuermann, J.P.; Hogle, J.M.; Coen, D.M. Unexpected features and mechanism of heterodimer formation of a herpesvirus nuclear egress complex. EMBO J. 2015, 34, 2937-2952. [CrossRef]

136. Muller, Y.A.; Häge, S.; Alkhashrom, S.; Höllriegl, T.; Weigert, S.; Dolles, S.; Hof, K.; Walzer, S.A.; Egerer-Sieber, C.; Conrad, M.; et al. High-resolution crystal structures of two prototypical $\beta$ - and $\gamma$-herpesviral nuclear egress complexes unravel the determinants of subfamily specificity. J. Biol. Chem. 2020, 295, 3189-3201. [CrossRef]

137. Dal Monte, P.; Pignatelli, S.; Zini, N.; Maraldi, N.M.; Perret, E.; Prevost, M.C.; Landini, M.P. Analysis of intracellular and intraviral localization of the human cytomegalovirus UL53 protein. J. Gen. Virol. 2002, 83, 1005-1012. [CrossRef]

138. Lischka, P.; Rosorius, O.; Trommer, E.; Stamminger, T. A novel transferable nuclear export signal mediates CRM1-independent nucleocytoplasmic shuttling of the human cytomegalovirus transactivator protein pUL69. EMBO J. 2001, 20, 7271-7283. [CrossRef]

139. Thomas, M.; Müller, R.; Horn, G.; Bogdanow, B.; Imami, K.; Milbradt, J.; Steingruber, M.; Marschall, M.; Schilling, E.M.; Fossen, T.; et al. Phosphosite analysis of the cytomegaloviral mRNA export factor pUL69 reveals serines with critical importance for recruitment of cellular proteins Pin1 and UAP56/URH49. J. Virol. 2020, 94, e02151-19. [CrossRef] 
140. Sharma, M.; Kamil, J.P.; Coen, D.M. Preparation of the Human Cytomegalovirus Nuclear Egress Complex and Associated Proteins. Methods Enzymol. 2016, 569, 517-526.

141. Muranyi, W.; Haas, J.; Wagner, M.; Krohne, G.; Koszinowski, U.H. Cytomegalovirus recruitment of cellular kinases to dissolve the nuclear lamina. Science 2002, 297, 854-857. [CrossRef]

142. Deutschmann, J.; Schneider, A.; Gruska, I.; Vetter, B.; Thomas, D.; Kießling, M.; Wittmann, S.; Herrmann, A.; Schindler, M.; Milbradt, J.; et al. A viral kinase counteracts in vivo restriction of murine cytomegalovirus by SAMHD1. Nat. Microbiol. 2019, 4, 2273-2284. [CrossRef]

143. Sanchez, V.; Spector, D.H. Cyclin-dependent kinase activity is required for efficient expression and posttranslational modification of human cytomegalovirus proteins and for production of extracellular particles. J. Virol. 2006, 80, 5886-5896. [CrossRef]

144. Adams, P.D. Regulation of the retinoblastoma tumor suppressor protein by cyclin/cdks. Biochim. Biophys. Acta 2001, 1471, M123-M133. [CrossRef]

145. Prichard, M.N.; Sztul, E.; Daily, S.L.; Perry, A.L.; Frederick, S.L.; Gill, R.B.; Hartline, C.B.; Streblow, D.N.; Varnum, S.M.; Smith, R.D.; et al. Human cytomegalovirus UL97 kinase activity is required for the hyperphosphorylation of retinoblastoma protein and inhibits the formation of nuclear aggresomes. J. Virol. 2008, 82, 5054-5067. [CrossRef]

146. Malumbres, M. Cyclin-dependent kinases. Genome Biol. 2014, 15, 122. [CrossRef]

147. Whittaker, S.R.; Mallinger, A.; Workman, P.; Clarke, P.A. Inhibitors of cyclin-dependent kinases as cancer therapeutics. Pharmacol. Ther. 2017, 173, 83-105. [CrossRef]

148. Chiu, H.C.; Huang, W.R.; Liao, T.L.; Chi, P.I.; Nielsen, B.L.; Liu, J.H.; Liu, H.J. Mechanistic insights into avian reovirus p17-modulated suppression of cell cycle CDK-cyclin complexes and enhancement of p53 and cyclin H interaction. J. Biol. Chem. 2018, 293, 12542-12562. [CrossRef]

149. Malumbres, M.; Harlow, E.; Hunt, T.; Hunter, T.; Lahti, J.M.; Manning, G.; Morgan, D.O.; Tsai, L.H.; Wolgemuth, D.J. Cyclin-dependent kinases: A family portrait. Nat. Cell Biol. 2009, 11, 1275-1276. [CrossRef]

150. Gautier, J.; Minshull, J.; Lohka, M.; Glotzer, M.; Hunt, T.; Maller, J.L. Cyclin is a component of maturation-promoting factor from Xenopus. Cell 1990, 60, 487-494. [CrossRef]

151. Lolli, G.; Lowe, E.D.; Brown, N.R.; Johnson, L.N. The crystal structure of human CDK7 and its protein recognition properties. Structure 2004, 12, 2067-2079. [CrossRef]

152. Toyoshima-Morimoto, F.; Taniguchi, E.; Shinya, N.; Iwamatsu, A.; Nishida, E. Polo-like kinase 1 phosphorylates cyclin B1 and targets it to the nucleus during prophase. Nature 2001, 410, 215-220. [CrossRef]

153. Yuan, J.; Eckerdt, F.; Bereiter-Hahn, J.; Kurunci-Csacsko, E.; Kaufmann, M.; Strebhardt, K. Cooperative phosphorylation including the activity of polo-like kinase 1 regulates the subcellular localization of cyclin B1. Oncogene 2002, 21, 8282-8292. [CrossRef]

154. Bigley, T.M.; Reitsma, J.M.; Terhune, S.S. Antagonistic Relationship between Human Cytomegalovirus pUL27 and pUL97 Activities during Infection. J. Virol. 2015, 89, 10230-10246. [CrossRef]

155. Garrett, S.; Barton, W.A.; Knights, R.; Jin, P.; Morgan, D.O.; Fisher, R.P. Reciprocal activation by cyclin-dependent kinases 2 and 7 is directed by substrate specificity determinants outside the T loop. Mol. Cell. Biol. 2001, 21, 88-99. [CrossRef] [PubMed]

156. Kim, J.B.; Sharp, P.A. Positive transcription elongation factor B phosphorylates hSPT5 and RNA polymerase II carboxyl-terminal domain independently of cyclin-dependent kinase-activating kinase. J. Biol. Chem. 2001, 276, 12317-12323. [CrossRef]

157. Martinez, A.M.; Afshar, M.; Martin, F.; Cavadore, J.C.; Labbe, J.C.; Doree, M. Dual phosphorylation of the T-loop in cdk7: Its role in controlling cyclin H binding and CAK activity. EMBO J. 1997, 16, 343-354. [CrossRef] [PubMed]

158. Mbonye, U.; Wang, B.; Gokulrangan, G.; Shi, W.; Yang, S.; Karn, J. Cyclin-dependent kinase 7 (CDK7)-mediated phosphorylation of the CDK9 activation loop promotes P-TEFb assembly with Tat and proviral HIV reactivation. J. Biol. Chem. 2018, 293, 10009-10025. [CrossRef] [PubMed]

159. Ramakrishnan, R.; Rice, A.P. Cdk9 T-loop phosphorylation is regulated by the calcium signaling pathway. J. Cell. Physiol. 2012, 227, 609-617. [CrossRef] [PubMed]

160. Russo, A.A.; Jeffrey, P.D.; Pavletich, N.P. Structural basis of cyclin-dependent kinase activation by phosphorylation. Nat. Struct. Biol. 1996, 3, 696-700. [CrossRef] 
161. Timofeev, O.; Cizmecioglu, O.; Settele, F.; Kempf, T.; Hoffmann, I. Cdc25 phosphatases are required for timely assembly of CDK1-cyclin B at the G2/M transition. J. Biol. Chem. 2010, 285, 16978-16990. [CrossRef]

162. Lees, J.A.; Buchkovich, K.J.; Marshak, D.R.; Anderson, C.W.; Harlow, E. The retinoblastoma protein is phosphorylated on multiple sites by human cdc2. EMBO J. 1991, 10, 4279-4290. [CrossRef]

163. Simone, C.; Bagella, L.; Bellan, C.; Giordano, A. Physical interaction between pRb and cdk9/cyclinT2 complex. Oncogene 2002, 21, 4158-4165. [CrossRef]

164. Ko, L.J.; Shieh, S.Y.; Chen, X.; Jayaraman, L.; Tamai, K.; Taya, Y.; Prives, C.; Pan, Z.Q. p53 is phosphorylated by CDK7-cyclin H in a p36MAT1-dependent manner. Mol. Cell. Biol. 1997, 17, 7220-7229. [CrossRef]

165. Nantajit, D.; Fan, M.; Duru, N.; Wen, Y.; Reed, J.C.; Li, J.J. Cyclin B1/Cdk1 phosphorylation of mitochondrial p53 induces anti-apoptotic response. PLoS ONE 2010, 5, e12341. [CrossRef] [PubMed]

166. Radhakrishnan, S.K.; Gartel, A.L. CDK9 phosphorylates p53 on serine residues 33, 315 and 392. Cell Cycle 2006, 5, 519-521. [CrossRef] [PubMed]

167. Heald, R.; McKeon, F. Mutations of phosphorylation sites in lamin A that prevent nuclear lamina disassembly in mitosis. Cell 1990, 61, 579-589. [CrossRef]

168. Ward, G.E.; Kirschner, M.W. Identification of cell cycle-regulated phosphorylation sites on nuclear lamin C. Cell 1990, 61, 561-577. [CrossRef]

169. Glover-Cutter, K.; Larochelle, S.; Erickson, B.; Zhang, C.; Shokat, K.; Fisher, R.P.; Bentley, D.L. TFIIH-associated Cdk7 kinase functions in phosphorylation of C-terminal domain Ser7 residues, promoter-proximal pausing, and termination by RNA polymerase II. Mol. Cell. Biol. 2009, 29, 5455-5464. [CrossRef]

170. Lolli, G. Binding to DNA of the RNA-polymerase II C-terminal domain allows discrimination between Cdk7 and Cdk9 phosphorylation. Nucleic Acids Res. 2009, 37, 1260-1268. [CrossRef]

171. Cribier, A.; Descours, B.; Valadao, A.L.; Laguette, N.; Benkirane, M. Phosphorylation of SAMHD1 by cyclin A2/CDK1 regulates its restriction activity toward HIV-1. Cell Rep. 2013, 3, 1036-1043. [CrossRef]

172. White, T.E.; Brandariz-Nunez, A.; Valle-Casuso, J.C.; Amie, S.; Nguyen, L.A.; Kim, B.; Tuzova, M.; Diaz-Griffero, F. The retroviral restriction ability of SAMHD1, but not its deoxynucleotide triphosphohydrolase activity, is regulated by phosphorylation. Cell Host Microbe 2013, 13, 441-451. [CrossRef]

173. Zhang, K.; Lv, D.-W.; Li, R. Conserved Herpesvirus Protein Kinases Target SAMHD1 to Facilitate Virus Replication. Cell Rep. 2019, 28, 449-459. [CrossRef]

174. Gentry, B.G.; Gentry, S.N.; Jackson, T.L.; Zemlicka, J.; Drach, J.C. Phosphorylation of antiviral and endogenous nucleotides to di- and triphosphates by guanosine monophosphate kinase. Biochem. Pharmacol. 2011, 81, 43-49. [CrossRef]

175. Biron, K.K.; Harvey, R.J.; Chamberlain, S.C.; Good, S.S.; Smith, A.A., 3rd; Davis, M.G.; Talarico, C.L.; Miller, W.H.; Ferris, R.; Dornsife, R.E.; et al. Potent and selective inhibition of human cytomegalovirus replication by $1263 \mathrm{~W} 94$, a benzimidazole L-riboside with a unique mode of action. Antimicrob. Agents Chemother. 2002, 46, 2365-2372. [CrossRef] [PubMed]

176. Marschall, M.; Strojan, H.; Kiener, R.; Wangen, C.; Sonntag, E.; Muller, R.; Zeittrager, I.; Wagner, S.; Stamminger, T.; Milbradt, J.; et al. Differential upregulation of host cell protein kinases by the replication of alpha-, beta- and gamma-herpesviruses provides a signature of virus-specific signalling. J. Gen. Virol. 2020, 101, 284-289. [CrossRef]

177. Mercorelli, B.; Sinigalia, E.; Loregian, A.; Palu, G. Human cytomegalovirus DNA replication: Antiviral targets and drugs. Rev. Med. Virol. 2008, 18, 177-210. [CrossRef] [PubMed]

178. Herget, T.; Freitag, M.; Morbitzer, M.; Kupfer, R.; Stamminger, T.; Marschall, M. Novel chemical class of pUL97 protein kinase-specific inhibitors with strong anticytomegaloviral activity. Antimicrob. Agents Chemother. 2004, 48, 4154-4162. [CrossRef] [PubMed]

179. Chou, S.; Ercolani, R.J.; Marousek, G.; Bowlin, T.L. Cytomegalovirus UL97 kinase catalytic domain mutations that confer multidrug resistance. Antimicrob. Agents Chemother. 2013, 57, 3375-3379. [CrossRef] [PubMed]

180. Biron, K.K. Maribavir: A Promising New Antiherpes Therapeutic Agent. In New Concepts of Antiviral Therapy; Springer: Boston, MA, USA, 2006.

181. Koszalka, G.W.; Johnson, N.W.; Good, S.S.; Boyd, L.; Chamberlain, S.C.; Townsend, L.B.; Drach, J.C.; Biron, K.K. Preclinical and toxicology studies of 1263W94, a potent and selective inhibitor of human cytomegalovirus replication. Antimicrob. Agents Chemother. 2002, 46, 2373-2380. [CrossRef] 
182. Lalezari, J.P.; Aberg, J.A.; Wang, L.H.; Wire, M.B.; Miner, R.; Snowden, W.; Talarico, C.L.; Shaw, S.; Jacobson, M.A.; Drew, W.L. Phase I dose escalation trial evaluating the pharmacokinetics, anti-human cytomegalovirus (HCMV) activity, and safety of 1263W94 in human immunodeficiency virus-infected men with asymptomatic HCMV shedding. Antimicrob. Agents Chemother. 2002, 46, 2969-2976. [CrossRef]

183. Ma, J.D.; Nafziger, A.N.; Villano, S.A.; Gaedigk, A.; Bertino, J.S., Jr. Maribavir pharmacokinetics and the effects of multiple-dose maribavir on cytochrome P450 (CYP) 1A2, CYP 2C9, CYP 2C19, CYP 2D6, CYP 3A, $\mathrm{N}$-acetyltransferase-2, and xanthine oxidase activities in healthy adults. Antimicrob. Agents Chemother. 2006, 50, 1130-1135. [CrossRef]

184. Marty, F.M.; Boeckh, M. Maribavir and human cytomegalovirus-what happened in the clinical trials and why might the drug have failed? Curr. Opin. Virol. 2011, 1, 555-562. [CrossRef]

185. Evers, D.L.; Komazin, G.; Shin, D.; Hwang, D.D.; Townsend, L.B.; Drach, J.C. Interactions among antiviral drugs acting late in the replication cycle of human cytomegalovirus. Antivir. Res. 2002, 56, 61-72. [CrossRef]

186. James, S.H.; Hartline, C.B.; Harden, E.A.; Driebe, E.M.; Schupp, J.M.; Engelthaler, D.M.; Keim, P.S.; Bowlin, T.L.; Kern, E.R.; Prichard, M.N. Cyclopropavir inhibits the normal function of the human cytomegalovirus UL97 kinase. Antimicrob. Agents Chemother. 2011, 55, 4682-4691. [CrossRef] [PubMed]

187. Chou, S.; Waldemer, R.H.; Senters, A.E.; Michels, K.S.; Kemble, G.W.; Miner, R.C.; Drew, W.L. Cytomegalovirus UL97 phosphotransferase mutations that affect susceptibility to ganciclovir. J. Infect. Dis. 2002, 185, 162-169. [CrossRef] [PubMed]

188. McSharry, J.J.; McDonough, A.; Olson, B.; Talarico, C.; Davis, M.; Biron, K.K. Inhibition of ganciclovir-susceptible and -resistant human cytomegalovirus clinical isolates by the benzimidazole L-riboside 1263W94. Clin. Diagn. Lab. Immunol. 2001, 8, 1279-1281. [CrossRef]

189. Williams, S.L.; Hartline, C.B.; Kushner, N.L.; Harden, E.A.; Bidanset, D.J.; Drach, J.C.; Townsend, L.B.; Underwood, M.R.; Biron, K.K.; Kern, E.R. In vitro activities of benzimidazole D- and L-ribonucleosides against herpesviruses. Antimicrob. Agents Chemother. 2003, 47, 2186-2192. [CrossRef] [PubMed]

190. Chou, S.; Marousek, G.I.; Senters, A.E.; Davis, M.G.; Biron, K.K. Mutations in the human cytomegalovirus UL27 gene that confer resistance to maribavir. J. Virol. 2004, 78, 7124-7130. [CrossRef] [PubMed]

191. Komazin, G.; Townsend, L.B.; Drach, J.C. Role of a mutation in human cytomegalovirus gene UL104 in resistance to benzimidazole ribonucleosides. J. Virol. 2004, 78, 710-715. [CrossRef] [PubMed]

192. Prichard, M.N.; Quenelle, D.C.; Bidanset, D.J.; Komazin, G.; Chou, S.; Drach, J.C.; Kern, E.R. Human cytomegalovirus UL27 is not required for viral replication in human tissue implanted in SCID mice. Virol. J. 2006, 3, 18. [CrossRef]

193. Breen, M.E.; Soellner, M.B. Small molecule substrate phosphorylation site inhibitors of protein kinases: Approaches and challenges. ACS Chem. Biol. 2015, 10, 175-189. [CrossRef]

194. Wilson, B.A.; Alam, M.S.; Guszczynski, T.; Jakob, M.; Shenoy, S.R.; Mitchell, C.A.; Goncharova, E.I.; Evans, J.R.; Wipf, P.; Liu, G.; et al. Discovery and Characterization of a Biologically Active Non-ATP-Competitive p38 MAP Kinase Inhibitor. J. Biomol. Screen. 2016, 21, 277-289. [CrossRef]

195. Gao, Y.; Zhang, P.; Cui, A.; Ye, D.Y.; Xiang, M.; Chu, Y. Discovery and anti-inflammatory evaluation of benzothiazepinones (BTZs) as novel non-ATP competitive inhibitors of glycogen synthase kinase-3beta (GSK-3beta). Bioorganic Med. Chem. 2018, 26, 5479-5493. [CrossRef]

196. Betzi, S.; Alam, R.; Martin, M.; Lubbers, D.J.; Han, H.; Jakkaraj, S.R.; Georg, G.I.; Schonbrunn, E. Discovery of a potential allosteric ligand binding site in CDK2. ACS Chem. Biol. 2011, 6, 492-501. [CrossRef] [PubMed]

197. Smith, R.D.; Lu, J.; Carlson, H.A. Are there physicochemical differences between allosteric and competitive ligands? PLoS Comput. Biol. 2017, 13, e1005813. [CrossRef] [PubMed]

198. Lanman, B.A.; Allen, J.R.; Allen, J.G.; Amegadzie, A.K.; Ashton, K.S.; Booker, S.K.; Chen, J.J.; Chen, N.; Frohn, M.J.; Goodman, G.; et al. Discovery of a Covalent Inhibitor of KRAS(G12C) (AMG 510) for the Treatment of Solid Tumors. J. Med. Chem. 2020, 63, 52-65. [CrossRef] [PubMed]

199. Canon, J.; Rex, K.; Saiki, A.Y.; Mohr, C.; Cooke, K.; Bagal, D.; Gaida, K.; Holt, T.; Knutson, C.G.; Koppada, N.; et al. The clinical KRAS(G12C) inhibitor AMG 510 drives anti-tumour immunity. Nature 2019, 575, $217-223$. [CrossRef] [PubMed]

(C) 2020 by the authors. Licensee MDPI, Basel, Switzerland. This article is an open access article distributed under the terms and conditions of the Creative Commons Attribution (CC BY) license (http://creativecommons.org/licenses/by/4.0/). 